\title{
The Impact of HIV Education on Behavior among Youths: A Propensity Score Matching Approach"
}

\author{
D. Mark Anderson \\ Department of Agricultural Economics and Economics \\ Montana State University \\ P.O. Box 172920 \\ Bozeman, MT 59717-2920 \\ Tel.: 14063660921 \\ E-mail address: dwight.anderson@montana.edu
}

January 2012

\begin{abstract}
There has been a long-standing debate as to whether sex or STI/HIV education actually influences the way young people behave. To the extent these programs work, they represent a potential mechanism policy-makers might use to reduce risky behavior among youths. This paper uses data from the 2009 Youth Risk Behavior Survey (YRBS) to examine if students who have received school-based HIV instruction behave differently than those who have not. To address potentially endogenous exposure to HIV education, this paper considers a propensity score matching (PSM) approach. Findings from the propensity score analysis suggest that standard ordinary least squares (OLS) results are biased. Despite this, there remains some evidence that exposure to HIV education decreases risky sexual activity. Among male students, HIV education is also negatively related to the rate of using needles to inject illegal drugs into the body. The needle use results are robust to a sensitivity analysis, while the results for sexual behaviors are not.
\end{abstract}

Keywords: HIV education; Risky behavior; Youth JEL Classification: H75; I18; I28; K32

\footnotetext{
* I owe thanks to Dean Anderson, Mike Hanlon, Shelly Lundberg, Claus Pörtner, Mary Schroeder, and participants at the 2010 Southern Economic Association's annual meeting for comments and suggestions. I also owe thanks to Lisa Whittle from the Centers for Disease Control and Prevention for help with obtaining the YRBS data. I gratefully acknowledge support from a Center for Studies in Demography and Ecology (CSDE) Traineeship, funded by the National Institute of Child Health and Human Development (NICHD). The views expressed herein are my own and do not necessarily reflect those held by the CSDE or the NICHD.
} 


\section{Introduction}

Approximately 1.1 million people in the United States were living with HIV in 2006 (Centers for Disease Control and Prevention (CDC) 2006). Nearly $30 \%$ of new HIV infections occur in people under the age of 30; and, the majority of young people are infected through sex (Hall et al. 2008; Kaiser Family Foundation 2005). Furthermore, adolescents represent a high risk group for contracting HIV and other sexually transmitted infections (STIs) (Hopkins et al. 2004). Despite the fact that $15-24$ year-olds represent only $25 \%$ of the United States population that is sexually active, these individuals account for nearly one-half of all new STIs (Weinstock et al. 2004).

Because risky sexual behavior increases the likelihood of contracting HIV and STIs, school-based sex and HIV educational courses represent potential policy instruments for affecting transmission rates among adolescents. Moreover, in promoting safer sex, causing a decrease in the frequency of intercourse, and/or delaying the sexual debut of youths, these programs could have positive effects beyond decreases in HIV and STI rates. Early virginity loss and sexual promiscuity have been shown to share a negative relationship with educational attainment, while the delay of one's sexual debut has been shown to be positively related to psychological well-being (Sabia and Rees 2008; Sabia and Rees 2009; Sabia and Rees 2011b). ${ }^{1}$ A reduction in risky sexual behavior may also decrease the incidence of teenage pregnancy. Evidence suggests that teenage pregnancy impedes the accumulation of human capital and decreases future earnings (Hoffman et al. 1993; Rosenzweig and Wolpin 1995; McElroy 1996;

\footnotetext{
${ }^{1}$ These results are for females only. Interestingly, Sabia and Rees (2011a) find that abstaining from sexual intercourse increases the probability that females graduate from high school, but has little effect on the educational attainment of males.
} 
Klepinger et al. 1999). ${ }^{2}$ Lastly, these courses may provide adolescents with a better understanding of human physiology and relationships (Marsiglio and Mott 1986).

The aim of this study is to examine the impact of school-based HIV education on risky behavior among youths. There are reasons to expect a negative relationship between HIV education and risky behavior. HIV education provides pertinent information to protecting oneself from contracting the virus. Information on the use of contraceptives, for example, may increase the probability a teen practices safe sex. Accurate information regarding the probability of contracting HIV and the consequences associated with infection can also be used by the individual when deciding whether or not to engage in sexual activity. If an individual's prior perceptions understate the true costs of sex, then we might expect HIV education to decrease the frequency of intercourse.

On the other hand, a positive relationship between HIV education and sexual activity may exist. If HIV education promotes the use of contraceptives, this could lead to an increase in protected sex but also to an increase in intercourse frequency due to a decrease in the perceived costs of sex. It is also possible that HIV instruction increases sexual activity by sending a signal of social approval of sex. Opponents typically criticize contraception-based HIV education on these grounds and either support abstinence-only programs or no school-based education at all (Collins et al. 2002).

To estimate the effect of school-based HIV instruction on youth behavior, this paper uses data from the 2009 Youth Risk Behavior Survey (YRBS). Findings from a propensity score matching (PSM) analysis suggest standard ordinary least squares (OLS) results are biased. Despite this, there remains some evidence that exposure to HIV education is negatively related to

\footnotetext{
${ }^{2}$ Evidence suggests that teenage pregnancy also has a positive effect on risky behaviors such as smoking (Webbink et al. 2008).
} 
sexual activity, and this result is strongest for males. There is also evidence that exposure to HIV education reduces the rate of needle use among male students. A Rosenbaum bounds sensitivity analysis illustrates the needle use results are robust to differing assumptions about the degree to which unobserved selection bias may remain in the PSM estimates. The PSM results for the sexual behavior outcomes are not robust to this sensitivity analysis.

This paper makes at least four important contributions to the literature. First, to the author's knowledge, it represents one of only three population-level studies to empirically acknowledge that exposure to sex and/or HIV education is likely endogenous. By noting large discrepancies between OLS and PSM results, this paper calls into question the findings that omit formal treatment of unobserved heterogeneity. Second, as this paper's focus is on HIV education, it is possible to evaluate the effects on non-sexual outcomes such as needle use. This is the first paper to consider self-selection effects and examine needle use among youths. This particular risky behavior is generally an emphasized component in the curriculums of HIV education and can have long-term health consequences that are just as grave as those related to risky sexual behavior. Third, the data analyzed here are from 2009 and represent the most up-todate national survey data used to evaluate school-based HIV education. This is crucial because the content emphasized in sex and HIV education classes has changed over time (Lindberg et al. 2006). ${ }^{3}$ Lastly, and perhaps most notably, the findings in this paper have important implications for understanding policy effectiveness in impacting risky youth behavior.

\footnotetext{
${ }^{3}$ While this paper relies on cross-sectional data and does not evaluate changes in these courses over time, it may be informative to compare the results presented here with those from previous studies that analyzed earlier data.
} 


\section{Background and Review of the Literature}

Schools have the capacity to reach a large number of young people and represent an established place where adolescents can receive HIV education. In the United States, HIV education is generally taught as a unit within health or physical education courses. Additionally, HIV education is regularly combined with instruction on the prevention of sexually transmitted infections. Because of this, research concerned with behavioral outcomes often focuses on the joint effects of HIV and STI education. In some school districts, HIV education represents a subset of more broadly defined sexual education classes, while in other districts HIV education is a separate unit. To be sure, differentiating between HIV education and sex education is not always straightforward. Most HIV and sex education classes share a common core of instruction about the risks of unprotected sex, the importance of reducing or delaying sexual activity, and methods of protection against STIs. A few topics, however, are distinct. For example, instruction about the sharing of intravenous needles clearly relates to HIV (Ku et al. 1992). Table A1 in the Appendix provides examples of lesson topics from curriculums for HIV education across six different states.

A margin on which HIV education differs across school districts and states that has been a topic of controversy is whether or not programs are comprehensive or abstinence-only. Comprehensive curricula include instruction on both abstinence and contraception, while abstinence-only education does not provide information on the use of contraceptives (Kaiser Family Foundation 2002). ${ }^{4}$

\footnotetext{
${ }^{4}$ Unfortunately, for the students in this study's sample, it is not possible to observe whether they have received comprehensive or abstinence-only education. However, the results were similar when considering subsets of the general sample that live in states where the law mandates that abstinence be "stressed" over other forms of contraception.
} 
Research regarding the efficacy of sex and HIV education is vast. Yet, despite the large amount of work done in this area, much is left to be desired. Research based on experimental designs with randomized assignment makes up a large portion of the literature. Certainly, these studies take causality seriously, but are usually conducted on specific, high-risk subgroups of the general population. Consequently, the generalizability of their results is questionable. Most quasi-experimental studies suffer from the same critique in addition to the problems inherent to non-random assignment. Kirby (2007) summarizes findings from 56 studies that were either experimental or quasi-experimental in nature. ${ }^{5}$ He concludes that a substantial percentage of sex and STI/HIV education programs decreased one or more types of risky sexual activity. The programs showed no evidence of increasing risky sexual behavior among adolescents.

A smaller amount of research has evaluated the effectiveness of these programs using national survey data. A benefit of using national survey data is that results can be informative about the general population. This approach also avoids the issues related to small sample sizes that are prevalent in the experimental and quasi-experimental literature. However, only a very few of the existing population-level studies formally consider that exposure to sex and HIV education is potentially endogenous. Table A2 summarizes papers that use national survey data to analyze the effects of sex and HIV education. Of the studies listed, only Oettinger (1999) and Sabia (2006) address empirically the influence of unobserved heterogeneity and selection bias.

Oettinger (1999) is the first to provide a rigorous theoretical treatment of how we might expect sex education to influence behavior. The sign of the relationship between sex education and behavior depends, in part, on the prior risk beliefs an individual associates with sexual activity. Oettinger (1999) tests his predictions using data from the 1979 National Longitudinal

\footnotetext{
${ }^{5}$ Of the studies evaluated, 33 employed an experimental design with random assignment, while the remaining 23 utilized a quasi-experimental approach.
} 
Survey of Youth. He estimates a proportional hazard model with same-sex sibling fixed effects to show that sex education is associated with earlier sexual activity for females and earlier pregnancy for certain subgroups of females. He finds no association between sex education and male transitions into sexual activity.

Using data from the National Longitudinal Study of Adolescent Health for 1994-1996, Sabia (2006) presents a thorough treatment of potentially endogenous sex education. He examines whether students who attend schools that offer sex education exhibit different sexual behaviors than students enrolled in schools where sex education is not taught. Using propensity score matching, difference-in-differences, and instrumental variable methods, Sabia (2006) finds little evidence to support a causal link between sex education and sexual activity.

Tremblay and Ling (2005) report performing a Hausman-type test to explore the endogeneity of HIV education. They fail to reject the null hypothesis of no specification errors and only report results where HIV education is assumed to be randomly assigned. ${ }^{6}$ The authors find no significant effects of HIV education on the probability of abstinence, but they do find that HIV education significantly increases the likelihood of condom-protected relative to unprotected intercourse.

\section{Data}

The data used in this paper come from the 2009 National Youth Risk Behavior Survey (YRBS). The YRBS data have been used by economists and policy analysts to study a broad

\footnotetext{
${ }^{6}$ In regards to the Hausman test, it has been shown that results are difficult to interpret and in some instances prove to be unreliable when the null is false (Dhrymes 1994).
} 
range of topics concerning policy evaluations and youth behavior. ${ }^{7}$ These surveys are conducted biennially by the Centers for Disease Control and Prevention and provide a nationally representative sample of U.S. high school students. ${ }^{8}$ The primary purpose of the YRBS is to collect information on youth activities that influence health. Each survey contains questions gauging the use of illegal substances, participation in risky sexual behaviors, daily eating and exercise habits, and other activities that might be considered harmful to an individual's health.

Table 1 lists and defines the variables used in this paper. The dependent variables of interest are indicators for whether or not the respondent has ever had sex, has had sex within the last three months, had condom protected sex during last intercourse, and used alcohol or drugs before last intercourse. Variables are also considered that document the total number of sexual partners the respondent reports having had in his/her lifetime and during the last three months. Lastly, a non-sexual outcome is analyzed, the respondent's report of having ever used a needle to inject an illegal drug into his/her body. This variable is considered because HIV education curriculums generally include lessons on non-sexual modes of transmission such as the sharing of needles. The variables documenting sexual activity within the last 3 months and drug/alcohol use before last intercourse are arguably preferred to the other measures of risky behavior because the timing of events is much less of a concern with these variables. ${ }^{9}$ In fact, the use of these

\footnotetext{
${ }^{7}$ For other studies that use the YRBS data, see, e.g., Anderson (2010) on the effect of an anti-methamphetamine campaign on teen meth use; Carpenter and Cook (2008) on the effect of cigarette taxes on youth smoking; Chatterji et al. (2004) on alcohol abuse and suicide attempts; Cawley et al. (2007) on the impact of state physical education requirements on youth physical activity and overweight; Grossman and Markowitz (2005) on risky sexual behavior and substance use; Katzman et al. (2007) on the social market for cigarettes.

${ }^{8}$ Though intended to be nationally representative, not all 50 states are represented in any given year the survey has been conducted.

${ }^{9}$ The concern remains, however, if a respondent's first exposure to HIV education came within the last 3 months before being interviewed.
} 
three variables represents an improvement to much of the population-level literature where the relative order of instruction and behaviors are not known. ${ }^{10}$

[Table 1 about here.]

The right-hand-side variable of interest is an indicator for whether or not the student reports having been taught about AIDS or HIV in school. ${ }^{11}$ For the sake of brevity, this variable will simply be referred to as the HIV education variable throughout the remainder of this paper. One concern with how this variable is measured is that of recall bias. For example, students who have received HIV education may or may not remember taking the course. If this type of measurement error is systematically related to risky behavior, then estimates may be biased. ${ }^{12}$ This concern, however, is mitigated by the fact that respondents were given the option to answer "not sure" to having ever received HIV education. For the results presented below, individuals who answered "not sure" were dropped from observation. ${ }^{13}$ Yet, it should be noted that results were qualitatively similar when the "not sure" responses were recorded to "no" or "yes" responses and included in the analyses. These estimates are available from the author upon request.

For the other independent variables used in this analysis, the YRBS data provide standard individual-level demographic characteristics. These variables include the age, grade, and race/ethnicity of the respondent. Variables on academic performance and the respondent's weight are included to control for possible self-selection into courses that offer HIV education

\footnotetext{
${ }^{10}$ See Kirby et al. (1994) for a review and discussion.

${ }^{11}$ With the exception of Sabia (2006), the studies listed in Table A2 are based on self-reported exposure to sex or HIV education in school. In most of the articles, the wording of the survey question is very similar to the wording of the question used here. Sabia (2006) uses school administrator reports on whether or not sex education is offered in their school. While the definition of HIV education used here is quite broad, it is worth pointing out that this paper does measure the impact of HIV education as it is actually being implemented throughout the United States. ${ }^{12}$ For example, more risky behaving students may be less likely to recall having received HIV education.

${ }^{13}$ This amounted to dropping 323 females and 267 males from the full sample.
} 
such as physical education (PE) and health education classes. Along these lines, a series of dummy variables describing the number of days spent per week in PE are also included on the right-hand-side. $^{14}$

A downside to the YRBS is the lack of family-level data. To control for potentially important household characteristics, this paper considers the amount of time the individual reports watching TV and sleeping per night on an average school day as proxies for family environment. Hours of TV viewing among children have been shown to be correlated with household socioeconomic status (Salmon et al. 2005), while hours of sleep have been related to family stress and parental education (Sadeh et al. 2000). Lastly, self-reports for whether the respondent has recently missed days of school for fear of their safety or has been offered, sold, or given an illegal drug on school property are included to proxy for school and community environment. ${ }^{15}$

\section{Empirical Strategy}

If exposure to HIV education in school was exogenous, then a simple OLS regression of sexual behavior on whether or not a student has learned about HIV would yield consistent estimates of the influence of HIV education on these behavioral outcomes. However, there are several reasons to believe why the assumption that exposure to HIV education is exogenous is unrealistic. First, in most schools, HIV education is included in the curriculums of elective courses such as health and physical education. To the extent the sexual behavior of individuals

\footnotetext{
${ }^{14}$ Because HIV education is often taught in physical education classes, it is possible the coefficients on the PE variables will pick up some of the influence of HIV education on the dependent variable. It should be noted, however, the results change little when the PE dummies are excluded from the analyses.

${ }^{15}$ It is important to mention that the proxies for family and school environment used in this paper may be endogenously determined. Because of this, OLS results are reported with and without these additional covariates.
} 
who enroll in these classes is systematically different from those who do not enroll, one may observe a correlation between HIV education and sexual behavior when no true causal relationship exists. Selection into these classes may occur due to individual-level choices or because of parental influence.

Second, local socio-economic conditions that are correlated with teen sexual activity may determine, in part, the availability of HIV education within schools. For example, poorer school districts may not be able to afford equivalent levels of HIV education compared to wealthier districts. Alternatively, wealthier districts may substitute away from courses that include HIV education in favor of advanced placement courses and classes designed to better prepare students for college. Community or school-level risky sexual behavior may also directly influence the adoption of HIV education. Kirby (2002) suggests sex and STI/HIV education programs are more commonly implemented in higher risk schools.

Third, the distributions of the covariates in the treated and control groups may lack common support. That is, there may be insufficient overlap in covariate values between the two groups such that the treatment group's covariates nearly perfectly predict assignment (Balsa and French 2010)

Lastly, OLS estimates can be biased towards zero if students misreport whether or not they have learned about HIV in school and this type of measurement error is correlated with sexual behavior. ${ }^{16}$

To estimate the impact of HIV education on behavior, this paper first considers the following equation:

\footnotetext{
${ }^{16}$ This type of measurement error is less of a concern since students were given the option to answer "not sure" to the HIV education question. As previously stated, results were fairly robust to recoding the "not sure" responses to "no" or "yes" responses.
} 


$$
\mathrm{Y}_{i}=\beta_{0}+\beta_{1} \mathrm{HIV} \mathrm{ED}_{i}+\mathbf{X}_{i} \boldsymbol{\beta}_{2}+\varepsilon_{i}
$$

where $i$ indexes the individual. The dependent variable $\mathrm{Y}_{i}$ represents one of the seven possible behavioral outcomes mentioned above. The treatment variable HIV_ED ${ }_{i}$ is a dummy equal to one if the individual reports having had HIV education in school and zero otherwise. $\mathbf{X}_{i}$ is a vector of the explanatory variables listed in Table 1. Lastly, in some estimations of (1), primary sampling unit effects are included to control for unobserved factors common to the respondent's area of residence. All regressions are estimated with OLS and are weighted by the sample weights provided with the YRBS data. When the outcome variable is binary, OLS estimation is equivalent to linear probability models. Results for the binary outcomes and the number of sexual partner outcomes were similar when estimating (1) with probit and tobit models, respectively. These results are available from the author upon request.

As mentioned above, exposure to HIV education may be correlated with factors that influence sexual behavior. One potential solution is to use instrumental variables that explain exposure to HIV education, but do not directly impact sexual behavior. Sabia (2006) considers instruments measured at the school-, census tract-, and county-levels that are likely correlated with school budgets and, hence, explain the availability of sex education within schools. ${ }^{17}$ However, if these variables are correlated with unobserved local factors that are correlated with sexual behavior, then they do not meet the necessary requirements of instrumental variables. ${ }^{18}$

Another method to address the problem of unobserved heterogeneity is to use propensity score matching (PSM) estimators (Rosenbaum and Rubin 1983). This approach consists of

\footnotetext{
${ }^{17}$ In particular, Sabia (2006) uses the following instrumental variables: percentage of teachers with Master's degrees, percentage of individuals in the census tract aged 3+ who attend private elementary schools or private high schools, percentage of never married men, and the county's share of votes cast for Bill Clinton in 1992.

${ }^{18}$ It should be noted that an instrumental variables approach was attempted using state-level HIV education mandates as instruments. However, the estimated first stage relationship was extremely small. As a result, there was not enough power to credibly estimate effect sizes on sexual activity.
} 
matching treated (i.e. those who have received HIV education) with untreated youths (i.e. those who have not received HIV education) based on their observable characteristics $\mathbf{X}$, and then comparing the behavior of treated and untreated individuals that have the same treatment propensity. The average treatment effect on the treated (ATT) is obtained by averaging individual-level differences in behavior between the treated and untreated.

There are several benefits to using PSM methods over more conventional methods such as OLS. First, matching estimators do not impose any functional form restrictions, nor do they assume the treatment effect is homogenous across populations (Zhao 2005). Second, while OLS uses the full sample for estimation, it is possible to confine estimation to matched sub-samples with propensity score techniques. Researchers have shown that using only matched observations reduces estimation bias relative to unmatched samples and estimates based on matching are generally more robust to model misspecifications (Conniffe et al. 2000; Rubin and Thomas 2000). Lastly, when performed correctly with quality data, PSM allows for legitimate comparisons between treated and control units and yields estimates that compare favorably with experimental studies (Smith and Todd 2001; Michalopoulos et al. 2004).

Following Becker and Ichino (2002), a treatment propensity $\mathrm{p}(\mathbf{X})$ for each observation in the sample is estimated. This step involves fitting a binary choice model, such as a logit regression, of whether or not one has received HIV education in school on the observable characteristics $\mathbf{X}$. The sample is then split into $k$ equally spaced intervals of the propensity score. Within each interval, it is tested whether the average propensity score of the treated units differs from that of the untreated units. If this test fails in an interval, the interval is split in half and retested. This process is repeated until, in all intervals, the average propensity score of treated 
and untreated units is the same. ${ }^{19}$ Then, within each interval, it is required that the means of each characteristic do not differ between treated and untreated observations. This condition is a necessary requirement of the Balancing Hypothesis. If this test fails, the model is re-estimated with the inclusion of interaction terms until the condition is satisfied. Lastly, treated and untreated youths are matched based on their propensity scores using an algorithm and the differences in their behavioral outcomes are calculated. ${ }^{20}$ The ATT is obtained by averaging these differences across all matches.

As it is not necessarily clear which algorithm should be implemented during the matching process, many papers present results from multiple techniques (see, e.g., Mocan and Tekin 2006 or Morris 2007). In general, the choice of one matching algorithm over another comes with certain trade-offs. In this paper, several approaches are considered. First, nearest neighbor matching with replacement is employed. In this algorithm, an individual from the comparison group is selected as a matching partner for an individual from the treated group that is nearest in terms of propensity score. Matching with replacement can minimize the propensity score distance between the matched control units and, as a result, can reduce bias because each treated unit can be matched to the nearest control even if a control unit has already been matched (Dehejia and Wahba 2002). The $k$-nearest neighbor matching approach is also considered where each treated individual is matched to multiple control units. ${ }^{21}$ This method involves a trade-off between reduced variance and increased bias. That is, variance is reduced because more

\footnotetext{
${ }^{19}$ Three evenly spaced bins were chosen as the starting point for this process. Table A3 illustrates the distributions of students by HIV education status within each interval.

${ }^{20}$ The algorithms considered were restricted to the "common support." This means that the test of the balancing property is conducted only on observations whose propensity score belongs to the intersection of the supports of the propensity score of the treated and control units. Imposing this condition may increase the quality of matches (Becker and Ichino 2002).

${ }^{21} k=3$ was chosen for this analysis.
} 
information is used to construct the counterfactual for each treated unit; but, increased bias results from poorer matches on average (Caliendo and Kopeinig 2005).

Next, within caliper and radius matching methods are used. If the nearest neighbor is a far distance away in terms of propensity score, then the methods discussed above face the risk that bad matches may be made. To overcome this issue, within caliper matching imposes a tolerance level on the maximum propensity score distance (i.e. the caliper) within which matching is permitted. Again, the trade-off is between the quality of the match and variance. Poor matches are avoided; however, the variance of the estimates increases if fewer matches are made. An issue with this approach is that it is not clear as to the level the caliper should be set (Smith and Todd 2005). As a result, the estimates presented below consider a range of maximum propensity score distances.

Radius matching, a modification of the within caliper approach, also requires specifying a maximum propensity score tolerance level for the matching process. With radius matching, the comparison unit is not only the nearest neighbor but all units within the caliper. An advantage of this technique is it permits usage of additional units when quality matches exist; or, it allows for the use of fewer units when good matches are not available (Caliendo and Kopeinig 2005).

Lastly, this paper considers kernel matching. Kernel-based matching constructs matches using all units in the potential control sample in a manner such that it places more weight on matches that are nearer by propensity score and less weight on more distant observations (Guo and Fraser 2010). The benefit of kernel-based matching is lower variance because more information is utilized. ${ }^{22}$

\footnotetext{
${ }^{22}$ The Epanechnikov kernel and a bandwidth of 0.06 were used for this analysis. These are the default settings for the psmatch2 command in STATA.
} 
Regardless of the matching algorithm implemented, it is important to mention that propensity score matching is not a cure-all. While this method allows for selection on observables, it still has a limitation that it shares with standard regression methods. That is, both methods require that, conditional on observed variables, the process by which individuals are selected into treatment be unrelated to unobserved variables that influence the outcome of interest (DiPrete and Gangl 2004). As a result, PSM estimates provide important information about the sign of the relationship and the strength of the association between HIV education and behavior, but do not necessarily imply causality. It is possible, however, to assess the sensitivity of the results to potential hidden bias with the Rosenbaum bounds approach (Rosenbaum 2002). This method allows the researcher to evaluate how strongly unobserved variables must influence selection into treatment in order to weaken the implications of the PSM analysis. DiPrete and Gangl (2004) comment that the Rosenbaum bounds approach can provide reasonable confidence that a causal relationship between a treatment and an outcome variable exists even in the presence of potential confounding variables.

To demonstrate the Rosenbaum bounds approach, assume the participation probability is given by

$$
P_{i}=P\left(\mathbf{X}_{i}, u_{i}\right)=P\left(\mathrm{HIV} \_\mathrm{ED}=1 \mid \mathbf{X}_{i}, u_{i}\right)=F\left(\mathbf{X}_{i} \boldsymbol{\beta}+\gamma u_{i}\right)
$$

where $\mathbf{X}$ are the observed characteristics for individual $i$ and $u_{i}$ is an unobserved component. If there exists no hidden bias which may influence the likelihood of treatment, then $\gamma=0$ and the participation probability is determined exclusively by $\mathbf{X}$. On the other hand, if hidden bias is present, then two individuals with identical $\mathbf{X}$ 's may have differing true probabilities of treatment. Assuming that $F(\bullet)$ represents the logistic distribution, the odds that individuals $i$ and $j$ receive treatment are $P_{i} /\left(1-P_{i}\right)$ and $P_{j} /\left(1-P_{j}\right)$, respectively. If both individuals have the same 
$\mathbf{X}$ 's, then the odds ratio can be shown to be equal to $\exp \left\{\gamma\left(u_{i}-u_{j}\right)\right\}$. Sensitivity analysis amounts to analyzing how altering values of $\gamma$ and $\left(u_{i}-u_{j}\right)$ changes inference about the impact of HIV education. Assuming $u_{i} \in\{0,1\}$, Rosenbaum (2002) shows that the following expression represents the bounds on the odds ratio that either of the two matched individuals will receive treatment:

$$
1 / e^{\gamma} \leq\left[P_{i}\left(1-P_{j}\right)\right] /\left[P_{j}\left(1-P_{i}\right)\right] \leq e^{\gamma}
$$

Clearly, if $e^{\gamma}=1$, then $i$ and $j$ have the same likelihood of being exposed to HIV education. If, for example, $e^{\gamma}=3$, then individuals who observationally appear similar could differ in their odds of receiving treatment by as much as a factor of 3 . The Rosenbaum bounds assess whether the confidence interval for the average treatment effect on the treated would include zero if an unobserved component caused the odds ratio of treatment assignment to differ between the treatment and comparison groups by a magnitude of $e^{\gamma}$ (Balsa and French 2010). Results are sensitive if values of $e^{\gamma}$ close to 1 could lead to inferences that are different from those obtained under the assumption that the study is free of hidden bias. In this case, PSM estimates are a less reliable tool to gauge whether results from OLS regressions are biased because the PSM estimates themselves are likely to be biased. Results are insensitive if large values of $e^{\gamma}$ are needed to change the inference (Rosenbaum 2002). For binary outcome variables, Aakvik (2001) suggests using the Mantel and Haenszel (1959) test statistic for assessing sensitivity. The Wilcoxon sign-rank test is recommended for continuous outcomes (Guo and Fraser 2010). 


\section{Results}

Tables 2 and 3 illustrate descriptive statistics for the full sample and the subsample of sexually experienced youths, respectively. ${ }^{23}$ Attention is restricted to sexually experienced individuals for much of the analysis because two of the outcome variables are relevant to only those students who report having had sex. In addition, the total number of sexual partner variables are only reported for the sexually experienced sample. Each table reports means for males and females separately and splits each sample into those who have had HIV education in school and those who have not. For males, the means of the behavioral outcome variables are statistically significantly different at the $5 \%$ level for all outcomes. The differences show that HIV education is associated with a lower frequency of sexual and risky behavior. For females in the full sample, the mean rate of needle use is statistically lower for those individuals who have been exposed to HIV education. Females in the sexually experienced sample who have had HIV education report higher rates of condom use during last intercourse, fewer recent sexual partners, and a lower rate of needle use.

[Table 2 about here.]

[Table 3 about here.]

It is also important to note the samples differ across some other potentially key observable characteristics. For instance, exposure to HIV education systematically varies by race and whether students missed days of school for fear of their safety, a proxy for school environment. These differences suggest exposure to HIV education may be endogenous at the school- or community-level. For example, schools in poorer districts that are associated with higher levels of risky behavior and lower levels of safety may be less likely to offer HIV

\footnotetext{
23 "Sexually experienced" means the individual has reported having had sexual intercourse during his/her life.
} 
education due to more restrictive budget constraints. Also, students that report receiving lower grades in school are less likely to report having received HIV education. This is consistent with the notion that certain types of students self-select into courses that teach HIV awareness.

\section{OLS results}

Table 4 presents the OLS results for males. Each cell represents a separate regression estimate and robust standard errors are reported in parentheses. Columns 1 through 3 illustrate results for the entire male sample, while Columns 4 through 6 show results for the subsample of males that report having had sexual intercourse. ${ }^{24}$ For outcomes that imply sexual activity (e.g. whether or not a condom was used during last intercourse), restricting the sample to only those who are sexually experienced is preferred. In Columns 1 and 4, only the basic individual controls listed in Tables 2 and 3 are included as right-hand-side variables. To assess the extent to which estimates may be biased due to unobserved heterogeneity, Columns 2 and 5 include controls for body weight status and PE attendance in addition to the proxies for home and school environment. Lastly, to better control for unobservables at larger geographic levels, such as a county, Columns 3 and 6 incorporate primary sampling unit (PSU) fixed effects. ${ }^{25}$

[Table 4 about here.]

The estimates in Table 4 show that exposure to HIV education is correlated with less sexual activity and risky behavior. This association is consistent with much of the literature (e.g., Furstenberg et al. 1985; Ku et al. 1992; Mueller et al. 2008), but is at odds with the initial

\footnotetext{
${ }^{24}$ Even though needle use is not a sexual behavior, it is informative to present results for this outcome in both samples. If one thinks of sexually experienced youths as a more "risky" group, then it is interesting to compare the magnitudes of treatment effects on nonsexual outcomes in this subsample with the sample in general.

${ }^{25}$ A PSU is either a county, a group of smaller bordering counties, or a sub-area of a very large county.
} 
correlations reported in Sabia (2006). ${ }^{26}$ In general, the magnitudes of the coefficient estimates become smaller when including the additional individual-level controls and proxies for home and school environment. Though this suggests unobserved heterogeneity may be important, the estimates remain relatively large and statistically significant in all but one case (i.e. condom use). The results change little when PSU fixed effects are included. Taken together, these estimates imply that if unobservables are confounding the results they are more likely to exist at the individual-, family-, or school-level than at a larger level of aggregation, such as a county or a state.

Table 5 shows the OLS results for females. Unlike the male results, there is less evidence that HIV education impacts the way females behave. While the signs of all the coefficients are consistent with the male findings, only the estimates for recent sex, recent number of sexual partners, and needle use are statistically significant. The recent sex coefficients are only significant in the model that restricts the sample to sexually experienced females. There is some evidence that females exposed to HIV education are more likely to report condom use during last intercourse, but this result is only statistically significant in the sparsest specification.

[Table 5 about here.]

It is interesting that HIV education is more strongly associated with less sexual activity and risky behavior among male students. While this is not the first study to illustrate stronger correlations among males, these results do not necessarily imply that male students are more responsive to school-based HIV instruction. ${ }^{27}$ Rather, it may simply be that selection bias is more prevalent among the males in the sample. The results from Tables 4 and 5 are from

\footnotetext{
${ }^{26}$ Sabia (2006) found that schools that adopted sex education at earlier grades had students who engaged in riskier behavior ("negative selection"). The results presented in this paper suggest "positive selection."

${ }^{27}$ Mueller et al. (2008) show exposure to sex education is positively and statistically significantly associated with virginity status among males only.
} 
regression models that do not consider the potential endogeneity of HIV education. As a result, they are likely to be unreliable (for both sexes) because of the bias due to selection as described in Section IV. Another concern is that regression specifications impose too much structure on the data. In what follows, estimates are presented from propensity score matching techniques that attempt to address important selection effects.

\section{PSM results}

Table 6 illustrates the PSM estimates for the full male sample. Each cell represents a separate estimate for an average treatment effect on the treated and bootstrapped standard errors are reported in parentheses. ${ }^{28}$ Column 1 presents the OLS estimates from Column 2 in Table 4 for the sake of comparison. Because the PSM method does not restrict matches to be made within each primary sampling unit, the PSM results are compared to the OLS estimates that omit primary sampling unit fixed effects. This is done throughout the remainder of the paper.

[Table 6 about here.]

The estimates in Table 6 support the interpretation of the OLS results in that HIV education is associated with less sexual activity and risky behavior. However, it should be noted the PSM estimates are generally smaller in magnitude than the OLS estimates. In some cases, this difference is quite large. This suggests the OLS estimates overstate the effects of HIV education due to selection on observables. Nonetheless, the magnitudes of the PSM results remain relatively large. For instance, males that report exposure to HIV education are 4.5 to 7.1 percentage points less likely to report having had sexual intercourse during the last 3 months. These estimates represent approximately 9.8 to 15.5 percent decreases from the mean rate of recent sex for the sample of males who report having not received HIV education in school.

\footnotetext{
${ }^{28}$ Bootstrapped standard errors are based on 200 replications.
} 
Lastly, it is worth mentioning the results for recent sex and needle use are less robust to the choice of matching algorithm. In particular, these estimates are sensitive to the choice of the tolerance level restriction for the within caliper technique.

The PSM estimates for the full female sample are presented in Table 7. While all of the estimates for sexual activity are negative in sign, none are statistically significant for the ever had sex outcome and only three are statistically significant for the recent sex outcome. The last row in Table 7 illustrates that the OLS needle use estimate is not robust to propensity score matching. Only the estimates for the $k$-nearest neighbor and kernel matching cases are statistically significant and these results are much smaller in magnitude than the OLS estimate.

[Table 7 about here.]

Table 8 shows the results for the sample of males who are sexually experienced. In this case, the PSM results are much different than the OLS estimates for the outcomes related to sexual activity. For the recent sex, number of lifetime partners, number of recent partners, and drug/alcohol use before last intercourse outcomes, the PSM estimates are much smaller than those from the OLS models. Furthermore, only the result for the number of lifetime partners in the $k$-nearest neighbor matching case is statistically significant. Many of the estimates show rather precisely estimated zero effects. Not only do these results imply that a strong bias is present in the OLS models, but they suggest the statistically significant estimates in Table 6 are primarily driven by the virgin males in the sample.

[Table 8 about here.]

Interestingly, the needle use estimate remains as the only outcome in Table 8 that is statistically significant across all PSM techniques. Again, the PSM estimates are smaller than those from OLS but, nonetheless, remain relatively large. 
The results in Table 9 for sexually experienced females tell a similar story as to the results for sexually experienced males in Table 8. The OLS estimates show that non-virgin females exposed to HIV education have statistically significantly lower rates of recent sex, fewer recent sexual partners, and lower rates of needle use. These three results, however, are not robust to propensity score matching. It is also worth mentioning that the condom use coefficients are positive and generally large in magnitude; yet, these estimates are statistically insignificant in all but two of the propensity score models.

[Table 9 about here.]

\section{Rosenbaum bounds}

The Rosenbaum bounds approach gauges the extent to which unobservables must influence the selection process in order to undermine the results from the PSM analysis. This method provides evidence on whether statistically significant results hinge on the untestable assumption that there are no unobserved variables that influence the selection into treatment (Becker and Caliendo 2007). Recall from above that $e^{\gamma}$ measures the influence of hidden bias on the probability of receiving HIV education. If $e^{\gamma}$ is assumed to be large, then individuals who have the same observed characteristics can differ in their odds of receiving treatment by a nontrivial factor.

For statistically significant average treatment effects on the treated, a magnitude of $e^{\gamma}$ (i.e. a critical value) is identified such that results become insignificant under the assumption of selection bias. In this procedure, two sets of p-values are produced: one under the assumption that treatment effects are overestimated and the other under the assumption that treatment effects 
are underestimated. If the p-value of the test statistic is significant for a particular magnitude of hidden bias, then one can conclude the estimate is fairly robust to the specified value of $e^{\gamma}{ }^{29}$

Table 10 reports the Rosenbaum bounds p-values under the assumption that those most likely to participate in HIV education are also less likely to participate in risky behaviors. The results displayed in Table 10 are for the needle use outcome for both male samples from the nearest neighbor matching routine. Given the estimated negative treatment effect, only the pvalues for the bounds under the assumption that the estimates are biased downward are reported. The first row illustrates results under the assumption of no hidden bias (i.e. when $e^{\gamma}=1$ ). The significance level on the bound becomes insignificant at the $10 \%$ level when $e^{\gamma}=4$ and $e^{\gamma}=3$ for the full male sample and the sexually experienced male sample, respectively. These critical values indicate the results are robust to a large degree of hidden bias.

[Table 10 about here.]

For the sake of brevity and because the needle use outcome for males was routinely the most robust PSM result, only the sensitivity analysis for this outcome is reported in a table format. ${ }^{30}$ However, it is important to mention that the remaining outcomes that appeared statistically significant in the PSM analysis were sensitive to small hidden biases. For example, for the full male sample, the critical value was 1.3 for the ever had sex and recent sex outcomes. ${ }^{31}$ For the full female sample, the critical value for the recent number of sexual

\footnotetext{
${ }^{29}$ Recall the Mantel and Haenszel test statistic is used when the outcome is binary and the Wilcoxon sign-rank test statistic is used otherwise. For more in depth discussions on bounding matching estimators and the use of the Mantel and Hanenszel and the Wilcoxon sign-rank statistics, see Aakvik (2001) and Guo and Fraser (2010), respectively.

${ }^{30}$ All other results are available from the author upon request.

${ }^{31}$ This critical value is based on a sensitivity of the results from the nearest neighbor matching algorithm.
} 
partners outcome was $1.2 .^{32}$ When restricting the sample to sexually experienced females, the critical value for the condom use result based on the kernel matching algorithm was 1.25.

Unlike the needle use results for males, the statistically significant estimates for the sexual outcome variables for both sexes appear sensitive to possible deviations from the unconfoundedness assumption. Consequently, caution is advised when interpreting these results. Yet, it is worth noting that a critical value of, say, $e^{\gamma}=1.2$ does not necessarily mean that unobserved heterogeneity exists and there is no effect of HIV education on sexual outcomes. This result merely means that the confidence interval for the effect would include zero if an unobserved variable caused the odds ratio of treatment assignment to differ between the treated and untreated groups by 1.2 (Becker and Caliendo 2007).

\section{Conclusion}

School-based HIV education represents a potential policy instrument for curbing risky activities among youths. HIV education may not only serve to reduce HIV and STI rates, but it could decrease dangerous non-sexual behaviors such as the sharing of hypodermic needles. To better inform the debate surrounding whether and what types of HIV education should be offered, credible estimates of the effects of these programs are required.

There is no shortage of research on the effects of sex or HIV education. However, nearly all of the population-level studies do not consider formally that exposure to HIV education is likely determined endogenously. This paper uses data from the 2009 Youth Risk Behavior Survey to estimate the effect of HIV education on risky youth behavior. A propensity score matching approach is taken that allows for selection on observables. Results from the propensity

\footnotetext{
${ }^{32}$ This critical value is based on a sensitivity of the results from the nearest neighbor matching algorithm.
} 
score analysis suggest that standard OLS estimates are biased. Yet, there remains some evidence that exposure to HIV education is negatively related to sexual activity. This result is strongest for males. In addition, HIV education shares a negative relationship with the rate of needle use among male students and a positive relationship with the rate of protected sex among female students; the latter result, however, is generally not statistically significant. A sensitivity analysis illustrates the needle use results are robust to differing assumptions about the degree to which unobserved selection bias may remain in the PSM estimates. The PSM results for the sexual behavior outcomes are substantially less robust to this sensitivity analysis.

It is important to note that this paper does not come without limitations. First, this study does not claim to have necessarily solved the endogeneity problem. Propensity score matching allows for selection on observables, but should not be treated as a silver bullet. However, by illustrating the direction of bias and the large discrepancies between OLS and PSM estimates, this research highlights the importance of selection effects in the relationship between HIV education and youth behavior. Future evaluations of these types of programs should take this source of bias seriously. Second, due to the nature of the data, HIV education was broadly defined. The empirical strategy above simply estimates the average effect of exposure and does not account for specific nuances in HIV education. More specifically, the analysis does not include information on the qualities of HIV education received. For example, some courses are relatively short in length, some cover only a few important topics and some incorporate participatory teaching methods. While previous research has addressed heterogeneous treatment effects, even these studies have failed to describe differences across programs in great detail. Future research may benefit from focusing on the particulars of instruction while simultaneously 
controlling for unobserved factors. Of course, collecting such detailed information at a population-level could be quite costly.

\section{Appendix}

[Table A1 about here.]

[Table A2 about here.]

[Table A3 about here.]

\section{References}

Aakvik, Arild. 2001. "Bounding a Matching Estimator: The Case of a Norwegian Training Program." Oxford Bulletin of Economics and Statistics 63: 115-143.

Anderson, D. Mark. 2010. "Does Information Matter? The Effect of the Meth Project on Meth Use among Youths." Journal of Health Economics 29: 732-742.

Anderson, John; Kann, Laura; Holtzman, Deborah; Arday, Susan; Truman, Ben and Kolbe, Lloyd. 1990. "HIV/AIDS Knowledge and Sexual Behavior among High School Students." Family Planning Perspectives 22: 252-255.

Balsa, Ana and French, Michael. 2010. "Alcohol Use and the Labor Market in Uruguay." Health Economics 19: 833-854.

Becker, Sascha and Caliendo, Marco. 2007. "Sensitivity Analysis for Average Treatment Effects." Stata Journal 7: 71-83.

Becker, Sascha and Ichino, Andrea. 2002. "Estimation of Average Treatment Effects Based on Propensity Scores.” Stata Journal 2: 358-377.

Billy, John; Brewster, Karin and Grady, William. 1994. "Contextual Effects on the Sexual Behavior of Adolescent Women." Journal of Marriage and the Family 56: 387-404.

Caliendo, Marco and Kopeinig, Sabine. 2005. "Some Practical Guidance for the Implementation of Propensity Score Matching.” IZA Discussion Paper No. 1588.

California Department of Education. 2011. HIV/STD Curriculum for California Schools. Date of Access: 26 February 2011. <http://www.cde.ca.gov/ls/he/se/curriculum.asp>.

Carpenter, Christopher and Cook, Philip. 2008. "Cigarette Taxes and Youth Smoking: New Evidence from National, State, and Local Youth Risk Behavior Surveys." Journal of 
Health Economics 27: 287-299.

Chatterji, Pinka; Dave, Daval; Kaestner, Robert and Markowitz, Sara. 2004. "Alcohol Abuse and Suicide Attempts among Youth." Economics and Human Biology 2: 159-180.

Cawley, John; Meyerhoefer, Chad and Newhouse, David. 2007. "The Impact of State Physical Education Requirements on Youth Physical Activity and Overweight." Health Economics 16: 1287-1301.

Centers for Disease Control and Prevention. 2006. "HIV Prevalence Estimates - United States, 2006." Morbidity and Mortality Weekly Report 57: 1073-1076.

Collins, Chris; Alagiri, Priya and Summers, Todd. 2002. “Abstinence Only vs. Comprehensive Sex Education: What are the Arguments? What is the Evidence?" AIDS Research Institute, University of California - San Francisco, Policy Monograph Series.

Conniffe, Denis; Gash, Vanessa and O'Connell, Philip. 2000. "Evaluating State Programmes: 'Natural Experiment' and Propensity Scores." Economic and Social Review 31: 283308.

Dawson, Deborah. 1986. “The Effects of Sex Education on Adolescent Behavior." Family Planning Perspectives 18: 162-170.

Dehejia, Rajeev and Wahba, Sadek. 2002. "Propensity Score-Matching Methods for Nonexperimental Causal Studies." Review of Economics and Statistics 84: 151-175.

Dhrymes, Phoebus. 1994. "Specification Tests in Simultaneous Equations Systems.” Journal of Econometrics 64: 45-76.

DiPrete, Thomas and Gangl, Markus. 2004. "Assessing Bias in the Estimation of Causal Effects: Rosenbaum Bounds on Matching Estimators and Instrumental Variables Estimation with Imperfect Instruments." Sociological Methodology 34: 271-310.

Furstenberg, Frank; Moore, Kristin and Peterson, James. 1985. "Sex Education and Sexual Experience among Adolescents." American Journal of Public Health 75: 1331-1332.

Grossman, Michael and Markowitz, Sara. 2005. "I Did What Last Night?! Adolescent Risky Sexual Behaviors and Substance Use." Eastern Economic Journal 31: 383-405.

Guo, Shenyang and Fraser, Mark. 2010. Propensity Score Analysis: Statistical Methods and Applications. SAGE Publications Inc.: United States.

Hall, H. Irene; Song, Ruiguang; Rhodes, Philip; Prejean, Joseph; An, Qian; Lee, Lisa; Karon, 
John; Brookmeyer, Ron; Kaplan, Edward; McKenna, Matthew and Janssen, Robert. 2008. "Estimation of HIV Incidence in the United States." Journal of the American Medical Association 300: 520-529.

Hoffman, Saul; Foster, Michael and Furstenberg Jr., Frank. 1993. "Reevaluating the Costs of Teenage Childbearing." Demography 30: 1-13.

Holtzman, Deborah; Lowry, Richard; Kann, Laura; Collins, Janet and Kolbe, Lloyd. 1994. "Changes in HIV-Related Information Sources, Instruction, Knowledge, and Behaviors among US High School Students, 1989 and 1990.” American Journal of Public Health 84: $388-393$.

Hopkins, Christopher; Tanner, Jr., John and Raymond, Mary Anne. 2004. "Risk Avoidance versus Risk Reduction: A Framework and Segmentation Profile for Understanding Adolescent Sexual Activity." Health Marketing Quarterly 21: 79-106.

Isley, Michelle; Edelman, Alison; Kaneshiro, Bliss; Peters, Dawn; Nichols, Mark and Jensen, Jeffrey. 2010. "Sex Education and Contraceptive Use at Coital Debut in the United States: Results from Cycle 6 of the National Survey of Family Growth." Contraception 82: $236-242$.

Kaiser Family Foundation. 2002. Sex Education in the U.S.: Policy and Politics. Date of Access: 2 June 2010. <http://www.kff.org/youthhivstds/upload/Sex-Education-in-the-US-Policy-and-Politics.pdf>.

Kaiser Family Foundation. 2005. U.S. Teen Sexual Activity. Date of Access: 28 April 2010. <http://www.kff.org/youthhivstds/upload/U-S-Teen-Sexual-Activity-Fact-Sheet.pdf>.

Katzman, Brett; Markowitz, Sara and McGeary, Kerry Anne. 2007. "An Empirical Investigation of the Social Market for Cigarettes." Health Economics 16: 1025-1039.

Kirby, Douglas. 2002. "The Impact of Schools and School Programs upon Adolescent Sexual Behavior." Journal of Sex Research 39: 27-33.

Kirby, Douglas. 2007. Emerging Answers: Research Findings on Programs to Reduce Teen Pregnancy and Sexually Transmitted Diseases. Washington, D.C.: The National Campaign to Prevent Teen Pregnancy.

Kirby, Douglas; Short, Lynn; Collins, Janet; Rugg, Deborah; Kolbe, Lloyd; Howard, Marion; Miller, Brent; Sonenstein, Freya and Zabin, Laurie. 1994. "School-Based Programs to Reduce Sexual Risk Behaviors: A Review of Effectiveness." Public Health Reports 109: 339-360.

Klepinger, Daniel; Lundberg, Shelly and Plotnick, Robert. 1999. "How Does Adolescent Fertility Affect the Human Capital and Wages of Young Women?" Journal of Human 
Resources 34: 421-448.

Kohler, Pamela; Manhart, Lisa and Lafferty, William. 2008. "Abstinence-Only and Comprehensive Sex Education and the Initiation of Sexual Activity and Teen Pregnancy." Journal of Adolescent Health 42: 344-351.

$\mathrm{Ku}$, Leighton; Sonenstein, Freya and Pleck, Joseph. 1992. “The Association of AIDS Education and Sex Education with Sexual Behavior and Condom Use among Teenage Men.” Family Planning Perspectives 24: 100-106.

$\mathrm{Ku}$, Leighton; Sonenstein, Freya and Pleck, Joseph. 1993. "Factors Influencing First Intercourse for Teenage Men.” Public Health Reports 108: 680-694.

Lindberg, Laura; Santelli, John and Singh, Susheela. 2006. "Changes in Formal Sex Education: 1995-2002." Perspectives on Sexual and Reproductive Health 38: 182-189

Manlove, Jennifer; Ikramullah, Erum and Terry-Humen, Elizabeth. 2008. "Condom Use and Consistency Among Male Adolescents in the United States." Journal of Adolescent Health 43: 325-333.

Mantel, Nathan and Haenszel, William. 1959. "Statistical Aspects of the Analysis of Data from Retrospective Studies." Journal of the National Cancer Institute 22: 719-748.

Marsiglio, William and Mott, Frank. 1986. "The Impact of Sex Education on Sexual Activity, Contraceptive Use and Premarital Pregnancy among American Teenagers." Family Planning Perspectives 18: 151-162.

Maryland Department of Education. 2011. HIV Prevention Education. Date of Access: 2 March 2011.

<http://www.marylandpublicschools.org/MSDE/divisions/studentschoolsvcs/student_ser vices_alt/HIV_AIDS_prevention/>.

Mauldon, Jane and Luker, Kristin. 1996. "The Effects of Contraceptive Education on Method Use at First Intercourse." Family Planning Perspectives 28: 19-24.

McElroy, Susan. 1996. "Early Childbearing, High School Completion, and College Enrollment: Evidence from 1980 High School Sophomores." Economics of Education Review 15: 303-324.

Michalopoulos, Charles; Bloom, Howard and Hill, Carolyn. 2004. "Can Propensity-Score Methods Match the Findings from a Random Assignment Evaluation of Mandatory Welfare-to-Work Programs?” Review of Economics and Statistics 86: 157-179.

Michigan Department of Education. 2011. HIV/STD and Sex Education Resource Documents. Date of Access: 1 March 2011. 
<http://www.michigan.gov/mde/0,1607,7-140-28753_38684_29233_29803-204637-,00.html>.

Mocan, Naci and Tekin, Erdal. 2006. "Catholic Schools and Bad Behavior: A Propensity Score Matching Analysis.” Contributions to Economic Analysis and Policy 5, Art. 13.

Morris, Stephen. 2007. "The Impact of Obesity on Employment.” Labour Economics 14: 413-433.

Mueller, Trisha; Gavin, Lorrie and Kulkarni, Aniket. 2008. "The Association Between Sex Education and Youth's Engagement in Sexual Intercourse, Age at First Intercourse, and Birth Control Use at First Sex.” Journal of Adolescent Health 42: 89-96.

New Hampshire Department of Education. 2011. High School Curriculum Guidelines. Date of Access: 24 February 2011.

<http://www.education.nh.gov/instruction/school_health/documents/curr_high.pdf>

NYC Department of Education. 2010. HIV/AIDS Curriculum. Date of Access: 2 June 2010. <http://schools.nyc.gov/Academics/FitnessandHealth/StandardsCurriculum/HIVAIDSov erview.htm>.

Oettinger, Gerald. 1999. "The Effects of Sex Education on Teen Sexual Activity and Teen Pregnancy." Journal of Political Economy 107: 606-644.

Rosenbaum, Paul. 2002. Observational Studies. 2nd edition. New York: Springer.

Rosenbaum, Paul and Rubin, Donald. 1983. "The Central Role of the Propensity Score in Observational Studies for Causal Effects.” Biometrika 70: 41-55.

Rosenzweig, Mark and Wolpin, Kenneth. 1995. "Sisters, Siblings, and Mothers: The Effect of Teen-Age Childbearing on Birth Outcomes in a Dynamic Family Context." Econometrica 63: 303-326.

Rubin, Donald and Thomas, Neal. 2000. "Combining Propensity Score Matching with Additional Adjustments for Progostic Covariates." Journal of the American Statistical Association 95: 573-585.

Sabia, Joseph. 2006. "Does Sex Education Affect Adolescent Sexual Behaviors and Health?" Journal of Policy Analysis and Management 25: 783-802.

Sabia, Joseph and Rees, Daniel. 2008. “The Effect of Adolescent Virginity Status on Psychological Well-Being." Journal of Health Economics 27: 1368-1381.

Sabia, Joseph and Rees, Daniel. 2009. “The Effect of Sexual Abstinence on Females' Educational Attainment." Demography 46: 695-715. 
Sabia, Joseph and Rees, Daniel. 2011a. "Boys will be Boys: Are there Gender Differences in the Effect of Sexual Abstinence on Schooling?" Health Economics 20: 287-305.

Sabia, Joseph and Rees, Daniel. 2011b. "Does the Number of Sex Partners Affect Educational Attainment?" Forthcoming in Journal of Population Economics.

Sadeh, Avi; Raviv, Amiram and Gruber, Reut. 2000. "Sleep Patterns and Sleep Disruptions in School-Age Children." Developmental Psychology 36: 291-301.

Salmon, Jo; Timperio, Anna; Telford, Amanda; Carver, Alison and Crawford, David. 2005.

"Association of Family Environment with Children's Television Viewing and with Low Level of Physical Activity." Obesity Research 13: 1939-1951.

Smith, Jeffrey and Todd, Petra. 2001. "Reconciling Conflicting Evidence on the Performance of Propensity-Score Matching Methods.” American Economic Review 91: 112-118.

Smith, Jeffrey and Todd, Petra. 2005. "Does Matching Overcome LaLonde's Critique of Nonexperimental Estimators?" Journal of Econometrics 125: 305-353.

Tremblay, Carol and Ling, Davina. 2005. "AIDS education, condom demand, and the sexual activity of American youth." Health Economics 14: 851-867.

Washington Office of Superintendent of Public Instruction. 2011. Minimum Content for HIV/AIDS Prevention Education Curriculum. Date of Access: 10 March 2011. <http://www.k12.wa.us/HIVSexualhealth/CurriculumContent.aspx>.

Webbink, Dinand; Martin, Nicholas and Visscher, Peter. 2008. "Does Teenage Childbearing Increase Smoking, Drinking and Body Size?” Journal of Health Economics 27: 888-903.

Weinstock, Hillard; Berman, Stuart and Cates, Jr., Willard. 2004. "Sexually Transmitted Diseases Among American Youth: Incidence and Prevalence Estimates, 2000." Perspectives on Sexual and Reproductive Health 36: 6-10.

Zhao, Zhong. 2005. "Sensitivity of Propensity Score Methods to the Specifications." Institute for the Study of Labor Discussion Paper No. 1873. 
Table 1: Variable definitions

\section{Dependent variables}

Ever had sex

Had sex within last 3 months

Total sex partners during lifetime

Total sex partners during last 3 months

Last sex with condom

Drug/alcohol use before last intercourse

Needle use

\section{Explanatory variables}

HIV education

Age 15 or younger

Age 16

Age 17

Age 18 or older

Grade 9

Grade 10

Grade 11

Grade 12

White

Black

Hispanic

Other race

Grades $=$ A's

Grades $=$ B's

Grades $=$ C's

Grades $=$ D's or F's

Underweight

Normal weight

Overweight or obese

$\mathrm{PE}=0$ days

$\mathrm{PE}=1$ or 2 days

$\mathrm{PE}=3$ or 4 days

$\mathrm{PE}=5$ days

$\mathrm{TV}=0$ hours

$\mathrm{TV}=<1$ to 2 hours

$\mathrm{TV}=3$ or 4 hours

$\mathrm{TV}=5$ hours or more

Sleep $=4$ hours or less

Sleep $=5$ or 6 hours

Sleep $=7$ or 8 hours

Sleep $=$ over 8 hours

Missed school for fear of safety

Offered drugs at school
$=1$ if ever had sexual intercourse, $=0$ otherwise

$=1$ if ever had sexual intercourse in the past 3 months, $=0$ otherwise

$=\#$ of people respondent has had intercourse with during life

$=\#$ of people respondent has had intercourse with during past 3 months

$=1$ if a condom was used during last intercourse, $=0$ otherwise

$=1$ if used alcohol or drugs before last intercourse, $=0$ otherwise

$=1$ if ever used a needle to inject an illegal drug into body, $=0$

otherwise

$=1$ if been taught about AIDS or HIV infection in school, $=0$ otherwise

$=1$ if less than or equal to 15 years of age, $=0$ otherwise

$=1$ if 16 years of age, $=0$ otherwise

$=1$ if 17 years of age, $=0$ otherwise

$=1$ if 18 years of age or older, $=0$ otherwise

$=1$ if in the $9^{\text {th }}$ grade, $=0$ otherwise

$=1$ if in the $10^{\text {th }}$ grade, $=0$ otherwise

$=1$ if in the $11^{\text {th }}$ grade, $=0$ otherwise

$=1$ if in the $12^{\text {th }}$ grade, $=0$ otherwise

$=1$ if white, $=0$ otherwise

$=1$ if black, $=0$ otherwise

$=1$ if Hispanic, $=0$ otherwise

$=1$ if other race, $=0$ otherwise

$=1$ if received mostly A's in school during past year, $=0$ otherwise

$=1$ if received mostly B's in school during past year, $=0$ otherwise

$=1$ if received mostly C's in school during past year, $=0$ otherwise

$=1$ if received mostly D's/F's in school during past year, $=0$ otherwise

$=1$ if BMI category is "underweight," $=0$ otherwise

$=1$ if BMI category is "normal weight," $=0$ otherwise

$=1$ if BMI category is "overweight" or "obese," $=0$ otherwise

$=1$ if goes to phys. ed. 0 days per school week, $=0$ otherwise

$=1$ if goes to phys. ed. 1 or 2 days per school week, $=0$ otherwise

$=1$ if goes to phys. ed. 3 or 4 days per school week, $=0$ otherwise

$=1$ if goes to phys. ed. 5 days per school week, $=0$ otherwise

$=1$ if watches $0 \mathrm{hrs}$. of TV per school day, $=0$ otherwise

$=1$ if watches $<1$ to 2 hours of TV per school day, $=0$ otherwise

$=1$ if watches 3 or 4 hours of TV per school day, $=0$ otherwise

$=1$ if watches 5 hours or more of TV per school day, $=0$ otherwise

$=1$ if sleeps 4 or less hours per school night, $=0$ otherwise

$=1$ if sleeps 5 or 6 hours per school night, $=0$ otherwise

$=1$ if sleeps 7 or 8 hours per school night, $=0$ otherwise

$=1$ if sleeps over 8 hours per school night, $=0$ otherwise

$=1$ if missed school during past month because felt unsafe at school or on way to or from school, $=0$ otherwise

$=1$ if offered, sold, or given illegal drug on school property during past year, $=0$ otherwise

Note: (1) Sample is 2009 National Youth Risk Behavior Survey. 
Table 2: Summary statistics: Means and standard deviations for full sample

\begin{tabular}{|c|c|c|c|c|}
\hline \multirow[b]{2}{*}{ Variable } & \multicolumn{2}{|l|}{ Males } & \multicolumn{2}{|l|}{ Females } \\
\hline & HIV ed. $=1$ & HIV ed. $=0$ & HIV ed. $=1$ & HIV ed. $=0$ \\
\hline \multicolumn{5}{|l|}{ Dependent variables } \\
\hline Ever had sex ${ }^{a}$ & $0.517(0.500)$ & $0.617(0.487)$ & $0.475(0.499)$ & $0.481(0.500)$ \\
\hline Had sex within last 3 months ${ }^{\mathrm{a}}$ & $0.360(0.480)$ & $0.459(0.499)$ & $0.367(0.482)$ & $0.395(0.489)$ \\
\hline Needle use $\mathrm{a}^{\mathrm{a}, \mathrm{b}}$ & $0.017(0.129)$ & $0.088(0.283)$ & $0.010(0.102)$ & $0.035(0.184)$ \\
\hline \multicolumn{5}{|l|}{ Basic individual controls } \\
\hline Age 15 or younger $^{\mathrm{b}}$ & $0.297(0.457)$ & $0.334(0.472)$ & $0.339(0.473)$ & $0.399(0.490)$ \\
\hline Age 16 & $0.258(0.438)$ & $0.245(0.430)$ & $0.251(0.434)$ & $0.240(0.428)$ \\
\hline Age $17^{\mathrm{b}}$ & $0.268(0.443)$ & $0.231(0.422)$ & $0.270(0.444)$ & $0.230(0.421)$ \\
\hline Age 18 or older & $0.177(0.381)$ & $0.189(0.392)$ & $0.140(0.347)$ & $0.131(0.337)$ \\
\hline Grade $9^{\mathrm{a}, \mathrm{b}}$ & $0.228(0.420)$ & $0.311(0.463)$ & $0.247(0.431)$ & $0.334(0.472)$ \\
\hline Grade 10 & $0.239(0.426)$ & $0.233(0.423)$ & $0.240(0.427)$ & $0.221(0.415)$ \\
\hline Grade $11^{\mathrm{a}}$ & $0.264(0.441)$ & $0.208(0.406)$ & $0.255(0.436)$ & $0.233(0.423)$ \\
\hline Grade $12^{\mathrm{b}}$ & $0.269(0.444)$ & $0.248(0.432)$ & $0.259(0.438)$ & $0.211(0.408)$ \\
\hline White ${ }^{a, b}$ & $0.483(0.500)$ & $0.331(0.471)$ & $0.452(0.498)$ & $0.303(0.460)$ \\
\hline Black & $0.147(0.354)$ & $0.154(0.361)$ & $0.161(0.368)$ & $0.146(0.354)$ \\
\hline Hispanic $^{\text {a, b }}$ & $0.181(0.385)$ & $0.253(0.435)$ & $0.181(0.385)$ & $0.319(0.466)$ \\
\hline Other race ${ }^{\mathrm{a}}$ & $0.146(0.353)$ & $0.206(0.405)$ & $0.159(0.366)$ & $0.181(0.386)$ \\
\hline Grades $=A^{\prime} s^{a}$ & $0.241(0.428)$ & $0.176(0.381)$ & $0.301(0.460)$ & $0.275(0.447)$ \\
\hline Grades $=B^{\prime} s^{a}$ & $0.372(0.484)$ & $0.323(0.468)$ & $0.386(0.487)$ & $0.352(0.478)$ \\
\hline Grades $=$ C's & $0.230(0.421)$ & $0.243(0.429)$ & $0.171(0.377)$ & $0.157(0.364)$ \\
\hline Grades $=$ D's or F's ${ }^{\mathrm{a}, \mathrm{b}}$ & $0.071(0.256)$ & $0.132(0.339)$ & $0.049(0.217)$ & $0.078(0.269)$ \\
\hline \multicolumn{5}{|c|}{ Additional individual controls and proxies for family/school environment } \\
\hline Underweight & $0.024(0.153)$ & $0.019(0.135)$ & $0.015(0.120)$ & $0.012(0.110)$ \\
\hline Normal weight ${ }^{\mathrm{a}, \mathrm{b}}$ & $0.635(0.482)$ & $0.546(0.498)$ & $0.682(0.466)$ & $0.631(0.483)$ \\
\hline Overweight or obese & $0.298(0.458)$ & $0.334(0.472)$ & $0.233(0.423)$ & $0.240(0.428)$ \\
\hline $\mathrm{PE}=0$ days & $0.403(0.491)$ & $0.390(0.488)$ & $0.455(0.498)$ & $0.415(0.493)$ \\
\hline $\mathrm{PE}=1$ or 2 days $^{\mathrm{a}, \mathrm{b}}$ & $0.056(0.230)$ & $0.093(0.291)$ & $0.056(0.230)$ & $0.094(0.292)$ \\
\hline $\mathrm{PE}=3$ or 4 days ${ }^{\mathrm{b}}$ & $0.122(0.328)$ & $0.123(0.329)$ & $0.121(0.326)$ & $0.152(0.359)$ \\
\hline $\mathrm{PE}=5$ days & $0.384(0.486)$ & $0.360(0.480)$ & $0.328(0.470)$ & $0.303(0.460)$ \\
\hline $\mathrm{TV}=0$ hours & $0.084(0.277)$ & $0.091(0.288)$ & $0.102(0.303)$ & $0.092(0.290)$ \\
\hline $\mathrm{TV}=<1$ to 2 hours $^{\mathrm{a}}$ & $0.556(0.497)$ & $0.461(0.499)$ & $0.553(0.497)$ & $0.531(0.499)$ \\
\hline $\mathrm{TV}=3$ or 4 hours & $0.258(0.438)$ & $0.282(0.450)$ & $0.238(0.426)$ & $0.232(0.422)$ \\
\hline $\mathrm{TV}=5$ hours or more $\mathrm{e}^{\mathrm{a}, \mathrm{b}}$ & $0.098(0.297)$ & $0.159(0.366)$ & $0.104(0.305)$ & $0.139(0.347)$ \\
\hline Sleep $=4$ hours or less $\mathrm{s}^{\mathrm{a}, \mathrm{b}}$ & $0.047(0.212)$ & $0.122(0.327)$ & $0.047(0.212)$ & $0.068(0.252)$ \\
\hline Sleep $=5$ or 6 hours $^{\mathrm{a}}$ & $0.284(0.451)$ & $0.231(0.422)$ & $0.333(0.471)$ & $0.305(0.461)$ \\
\hline Sleep $=7$ or 8 hours $^{\mathrm{a}}$ & $0.533(0.499)$ & $0.466(0.499)$ & $0.491(0.500)$ & $0.451(0.498)$ \\
\hline Sleep $=$ over 8 hours $^{\mathrm{a}, \mathrm{b}}$ & $0.081(0.273)$ & $0.113(0.317)$ & $0.062(0.242)$ & $0.091(0.287)$ \\
\hline Missed school for fear of safety ${ }^{\mathrm{a}, \mathrm{b}}$ & $0.039(0.194)$ & $0.101(0.302)$ & $0.049(0.216)$ & $0.099(0.299)$ \\
\hline Offered drugs at school & $0.276(0.447)$ & $0.307(0.462)$ & $0.202(0.402)$ & $0.214(0.411)$ \\
\hline $\mathrm{N}$ & 5936 & 592 & 6409 & 574 \\
\hline
\end{tabular}

Notes: (1) ${ }^{a}$ Means are statistically different at 5\% level for males who have had HIV education versus those who have not. ${ }^{b}$ Means are statistically different at 5\% level for females who have had HIV education versus those who have not. (2) Sample is 2009 National Youth Risk Behavior Survey. (3) Standard deviations are in parentheses. 
Table 3: Summary statistics: Means and standard deviations for sexually experienced sample

\begin{tabular}{|c|c|c|c|c|}
\hline \multirow[b]{2}{*}{ Variable } & \multicolumn{2}{|l|}{ Males } & \multicolumn{2}{|l|}{ Females } \\
\hline & HIV ed. = 1 & HIV ed. $=0$ & HIV ed. = 1 & HIV ed. $=0$ \\
\hline \multicolumn{5}{|l|}{ Dependent variables } \\
\hline Had sex within last 3 months $^{\mathrm{a}}$ & $0.695(0.460)$ & $0.745(0.436)$ & $0.773(0.419)$ & $0.822(0.383)$ \\
\hline Total sex partners during lifetime ${ }^{\mathrm{a}}$ & $3.033(1.935)$ & $3.504(2.054)$ & $2.523(1.710)$ & $2.710(1.771)$ \\
\hline Total sex partners during last 3 months ${ }^{\mathrm{a}, \mathrm{b}}$ & $1.219(1.381)$ & $1.775(1.943)$ & $0.994(0.838)$ & $1.322(1.349)$ \\
\hline Last sex with condom ${ }^{\mathrm{a}, \mathrm{b}}$ & $0.697(0.460)$ & $0.622(0.486)$ & $0.578(0.494)$ & $0.482(0.501)$ \\
\hline Drug/alcohol use before last intercourse ${ }^{a}$ & $0.216(0.412)$ & $0.304(0.461)$ & $0.155(0.362)$ & $0.199(0.400)$ \\
\hline Needle use ${ }^{\mathrm{a}, \mathrm{b}}$ & $0.031(0.172)$ & $0.134(0.341)$ & $0.019(0.136)$ & $0.072(0.260)$ \\
\hline \multicolumn{5}{|l|}{ Basic individual controls } \\
\hline Age 15 or younger ${ }^{b}$ & $0.204(0.403)$ & $0.233(0.423)$ & $0.208(0.406)$ & $0.308(0.462)$ \\
\hline Age 16 & $0.239(0.427)$ & $0.247(0.432)$ & $0.248(0.432)$ & $0.221(0.416)$ \\
\hline Age $17^{\mathrm{a}}$ & $0.322(0.467)$ & $0.268(0.444)$ & $0.337(0.473)$ & $0.290(0.455)$ \\
\hline Age 18 or older & $0.234(0.424)$ & $0.252(0.435)$ & $0.207(0.405)$ & $0.181(0.386)$ \\
\hline Grade $9^{\mathrm{a}, \mathrm{b}}$ & $0.162(0.368)$ & $0.227(0.420)$ & $0.151(0.358)$ & $0.232(0.423)$ \\
\hline Grade 10 & $0.206(0.405)$ & $0.241(0.428)$ & $0.202(0.402)$ & $0.228(0.420)$ \\
\hline Grade $11^{\mathrm{a}}$ & $0.291(0.454)$ & $0.211(0.409)$ & $0.294(0.456)$ & $0.279(0.449)$ \\
\hline Grade $12^{\mathrm{b}}$ & $0.341(0.474)$ & $0.321(0.467)$ & $0.352(0.478)$ & $0.261(0.440)$ \\
\hline White $^{\mathrm{a}, \mathrm{b}}$ & $0.417(0.493)$ & $0.296(0.457)$ & $0.440(0.496)$ & $0.312(0.464)$ \\
\hline Black & $0.211(0.408)$ & $0.200(0.401)$ & $0.209(0.406)$ & $0.185(0.389)$ \\
\hline Hispanic $^{\mathrm{a}, \mathrm{b}}$ & $0.194(0.396)$ & $0.255(0.436)$ & $0.174(0.379)$ & $0.293(0.456)$ \\
\hline Other race ${ }^{a}$ & $0.157(0.364)$ & $0.222(0.416)$ & $0.159(0.365)$ & $0.185(0.389)$ \\
\hline Grades $=$ As & $0.158(0.365)$ & $0.134(0.341)$ & $0.228(0.420)$ & $0.185(0.389)$ \\
\hline Grades $=\mathrm{Bs}^{\mathrm{a}}$ & $0.360(0.480)$ & $0.293(0.456)$ & $0.394(0.489)$ & $0.366(0.483)$ \\
\hline Grades $=\mathrm{Cs}$ & $0.286(0.452)$ & $0.282(0.451)$ & $0.218(0.413)$ & $0.214(0.411)$ \\
\hline Grades $=$ Ds or Fs ${ }^{\mathrm{a}, \mathrm{b}}$ & $0.098(0.297)$ & $0.175(0.381)$ & $0.064(0.245)$ & $0.112(0.316)$ \\
\hline \multicolumn{5}{|c|}{ Additional individual controls and proxies for family/school environment } \\
\hline Underweight & $0.023(0.150)$ & $0.016(0.127)$ & $0.012(0.111)$ & $0.014(0.120)$ \\
\hline Normal weight ${ }^{\mathrm{a}, \mathrm{b}}$ & $0.633(0.482)$ & $0.570(0.496)$ & $0.693(0.461)$ & $0.620(0.486)$ \\
\hline Overweight or obese & $0.303(0.460)$ & $0.299(0.458)$ & $0.236(0.425)$ & $0.264(0.442)$ \\
\hline $\mathrm{PE}=0$ days & $0.406(0.491)$ & $0.408(0.492)$ & $0.512(0.500)$ & $0.471(0.500)$ \\
\hline $\mathrm{PE}=1$ or 2 days $^{\mathrm{a}, \mathrm{b}}$ & $0.066(0.248)$ & $0.096(0.295)$ & $0.059(0.236)$ & $0.116(0.321)$ \\
\hline $\mathrm{PE}=3$ or 4 days & $0.114(0.318)$ & $0.123(0.329)$ & $0.104(0.306)$ & $0.109(0.312)$ \\
\hline $\mathrm{PE}=5$ days & $0.380(0.485)$ & $0.340(0.474)$ & $0.291(0.454)$ & $0.279(0.449)$ \\
\hline $\mathrm{TV}=0$ hours & $0.077(0.267)$ & $0.082(0.275)$ & $0.095(0.294)$ & $0.087(0.282)$ \\
\hline $\mathrm{TV}=<1$ to 2 hours $^{\mathrm{a}}$ & $0.542(0.498)$ & $0.455(0.499)$ & $0.543(0.498)$ & $0.493(0.501)$ \\
\hline $\mathrm{TV}=3$ or 4 hours & $0.263(0.440)$ & $0.255(0.436)$ & $0.238(0.426)$ & $0.243(0.430)$ \\
\hline $\mathrm{TV}=5$ hours or more ${ }^{\mathrm{a}, \mathrm{b}}$ & $0.111(0.314)$ & $0.203(0.403)$ & $0.120(0.325)$ & $0.170(0.377)$ \\
\hline Sleep $=4$ hours or less ${ }^{\mathrm{a}, \mathrm{b}}$ & $0.061(0.240)$ & $0.159(0.366)$ & $0.052(0.222)$ & $0.094(0.293)$ \\
\hline Sleep $=5$ or 6 hours $^{\mathrm{a}}$ & $0.326(0.469)$ & $0.249(0.433)$ & $0.365(0.481)$ & $0.355(0.479)$ \\
\hline Sleep $=7$ or 8 hours $^{a}$ & $0.498(0.500)$ & $0.419(0.494)$ & $0.476(0.500)$ & $0.424(0.495)$ \\
\hline Sleep $=$ over 8 hours $^{\mathrm{a}}$ & $0.059(0.235)$ & $0.110(0.313)$ & $0.056(0.231)$ & $0.076(0.266)$ \\
\hline Missed school for fear of safety ${ }^{a, b}$ & $0.056(0.230)$ & $0.151(0.358)$ & $0.062(0.241)$ & $0.134(0.341)$ \\
\hline Offered drugs at school & $0.354(0.478)$ & $0.395(0.489)$ & $0.253(0.435)$ & $0.279(0.449)$ \\
\hline $\mathrm{N}$ & 3071 & 365 & 3047 & 276 \\
\hline
\end{tabular}

Notes: (1) ${ }^{a}$ Means are statistically different at 5\% level for males who have had HIV education versus those who have not. ${ }^{\mathrm{b}}$ Means are statistically different at 5\% level for females who have had HIV education versus those who have not. (2) Sample is 2009 National Youth Risk Behavior Survey. (3) Standard deviations are in parentheses. 
Table 4: Effect of HIV education on behavioral outcomes (OLS results for males)

\begin{tabular}{|c|c|c|c|c|c|c|}
\hline \multirow[b]{2}{*}{ Dependent Variable } & \multicolumn{3}{|c|}{ Full male sample $(\mathrm{N}=6528)$} & \multicolumn{3}{|c|}{ Sexually experienced male sample $(\mathrm{N}=3436)$} \\
\hline & $(1)$ & $(2)$ & (3) & $(4)$ & (5) & (6) \\
\hline Ever had sex & $\begin{array}{l}-0.088 * * * \\
(0.026)\end{array}$ & $\begin{array}{l}-0.083 * * * \\
(0.025)\end{array}$ & $\begin{array}{l}-0.080 * * * \\
(0.024)\end{array}$ & --- & --- & --- \\
\hline Had sex within last 3 months & $\begin{array}{l}-0.121 * * * \\
(0.026)\end{array}$ & $\begin{array}{l}-0.115 * * * \\
(0.025)\end{array}$ & $\begin{array}{l}-0.111 * * * \\
(0.025)\end{array}$ & $\begin{array}{l}-0.103 * * * \\
(0.030)\end{array}$ & $\begin{array}{l}-0.094 * * * \\
(0.031)\end{array}$ & $\begin{array}{l}-0.091 * * * \\
(0.030)\end{array}$ \\
\hline Total sex partners during lifetime & --- & --- & --- & $\begin{array}{l}-0.475 * * * \\
(0.155)\end{array}$ & $\begin{array}{l}-0.311 * * \\
(0.143)\end{array}$ & $\begin{array}{l}-0.315^{* *} \\
(0.142)\end{array}$ \\
\hline Total sex partners during last 3 months & --- & --- & --- & $\begin{array}{l}-0.700 * * * \\
(0.136)\end{array}$ & $\begin{array}{l}-0.477 * * * \\
(0.109)\end{array}$ & $\begin{array}{l}-0.475 * * * \\
(0.108)\end{array}$ \\
\hline Last sex with condom & --- & --- & --- & $\begin{array}{l}0.090 * * \\
(0.037)\end{array}$ & $\begin{array}{l}0.053 \\
(0.035)\end{array}$ & $\begin{array}{l}0.053 \\
(0.035)\end{array}$ \\
\hline $\begin{array}{l}\text { Drug or alcohol use before } \\
\text { last intercourse }\end{array}$ & --- & --- & --- & $\begin{array}{l}-0.106 * * * \\
(0.035)\end{array}$ & $\begin{array}{l}-0.071 * * \\
(0.033)\end{array}$ & $\begin{array}{l}-0.058 * \\
(0.033)\end{array}$ \\
\hline Needle use & $\begin{array}{l}-0.063 * * * \\
(0.014)\end{array}$ & $\begin{array}{l}-0.045 * * * \\
(0.010)\end{array}$ & $\begin{array}{l}-0.048 * * * \\
(0.010)\end{array}$ & $\begin{array}{l}-0.100 * * * \\
(0.023)\end{array}$ & $\begin{array}{l}-0.057 * * * \\
(0.016)\end{array}$ & $\begin{array}{l}-0.063 * * * \\
(0.016)\end{array}$ \\
\hline Basic individual controls & Yes & Yes & Yes & Yes & Yes & Yes \\
\hline $\begin{array}{l}\text { Additional individual controls and } \\
\text { proxies for family/school environment }\end{array}$ & No & Yes & Yes & No & Yes & Yes \\
\hline Primary sampling unit fixed effects & No & No & Yes & No & No & Yes \\
\hline
\end{tabular}

Notes: (1) Sample is 2009 National Youth Risk Behavior Surveys. (2) Each cell represents a separate regression. (3) Control variables are described in Table 1 and summarized in Tables 2 and 3. (4) Robust standard errors are in parentheses. (5) *, significant at $10 \%$ level; **, significant at 5\% level; ***, significant at $1 \%$ level. 
Table 5: Effect of HIV education on behavioral outcomes (OLS results for females)

\begin{tabular}{|c|c|c|c|c|c|c|}
\hline \multirow[b]{2}{*}{ Dependent Variable } & \multicolumn{3}{|c|}{ Full female sample $(\mathrm{N}=6983)$} & \multicolumn{3}{|c|}{ Sexually experienced female sample $(\mathrm{N}=3323)$} \\
\hline & (1) & (2) & (3) & $(4)$ & (5) & (6) \\
\hline Ever had sex & $\begin{array}{l}-0.019 \\
(0.029)\end{array}$ & $\begin{array}{l}-0.009 \\
(0.027)\end{array}$ & $\begin{array}{l}-0.003 \\
(0.027)\end{array}$ & --- & --- & --- \\
\hline Had sex within last 3 months & $\begin{array}{l}-0.040 \\
(0.028)\end{array}$ & $\begin{array}{l}-0.033 \\
(0.026)\end{array}$ & $\begin{array}{l}-0.030 \\
(0.027)\end{array}$ & $\begin{array}{l}-0.057 * * \\
(0.029)\end{array}$ & $\begin{array}{l}-0.059 * * \\
(0.030)\end{array}$ & $\begin{array}{l}-0.069 * * \\
(0.031)\end{array}$ \\
\hline Total sex partners during lifetime & --- & --- & --- & $\begin{array}{l}-0.203 \\
(0.143)\end{array}$ & $\begin{array}{l}-0.138 \\
(0.140)\end{array}$ & $\begin{array}{l}-0.157 \\
(0.141)\end{array}$ \\
\hline Total sex partners during last 3 months & --- & --- & --- & $\begin{array}{l}-0.317 * * * \\
(0.118)\end{array}$ & $\begin{array}{l}-0.274 * * \\
(0.114)\end{array}$ & $\begin{array}{l}-0.293 * * \\
(0.118)\end{array}$ \\
\hline Last sex with condom & --- & --- & --- & $\begin{array}{l}0.075^{*} \\
(0.041)\end{array}$ & $\begin{array}{l}0.066 \\
(0.041)\end{array}$ & $\begin{array}{l}0.063 \\
(0.041)\end{array}$ \\
\hline $\begin{array}{l}\text { Drug or alcohol use before } \\
\text { last intercourse }\end{array}$ & --- & --- & --- & $\begin{array}{l}-0.043 \\
(0.034)\end{array}$ & $\begin{array}{l}-0.023 \\
(0.031)\end{array}$ & $\begin{array}{l}-0.025 \\
(0.031)\end{array}$ \\
\hline Needle use & $\begin{array}{l}-0.029 * * \\
(0.012)\end{array}$ & $\begin{array}{l}-0.024 * * \\
(0.012)\end{array}$ & $\begin{array}{l}-0.026 * * \\
(0.012)\end{array}$ & $\begin{array}{l}-0.062 * * \\
(0.025)\end{array}$ & $\begin{array}{l}-0.051 * * \\
(0.023)\end{array}$ & $\begin{array}{l}-0.054 * * \\
(0.023)\end{array}$ \\
\hline Basic individual controls & Yes & Yes & Yes & Yes & Yes & Yes \\
\hline $\begin{array}{l}\text { Additional individual controls and } \\
\text { proxies for family/school environment }\end{array}$ & No & Yes & Yes & No & Yes & Yes \\
\hline Primary sampling unit fixed effects & No & No & No & No & Yes & Yes \\
\hline
\end{tabular}

Notes: (1) Sample is 2009 National Youth Risk Behavior Surveys. (2) Each cell represents a separate regression. (3) Control variables are described in Table 1 and summarized in Tables 2 and 3. (4) Robust standard errors are in parentheses. (5) *, significant at $10 \%$ level; **, significant at 5\% level; ***, significant at $1 \%$ level. 
Table 6: Effect of HIV education on behavioral outcomes (PSM results for full male sample)

\begin{tabular}{|c|c|c|c|c|c|c|c|c|}
\hline Dependent Variable & $\begin{array}{l}\text { OLS results } \\
\text { for comparison } \\
(\mathrm{N}=6528) \\
\text { (1) }\end{array}$ & $\begin{array}{l}\text { Nearest } \\
\text { neighbor } \\
(\mathrm{N}=6517) \\
(2)\end{array}$ & $\begin{array}{l}k \text {-nearest } \\
\text { neighbor } \\
(\mathrm{N}=6517) \\
(3)\end{array}$ & $\begin{array}{l}\text { Within caliper } \\
(\delta=0.001) \\
(\mathrm{N}=6347) \\
(4)\end{array}$ & $\begin{array}{l}\text { Within caliper } \\
(\delta=0.0001) \\
(\mathrm{N}=3840) \\
(5)\end{array}$ & $\begin{array}{l}\text { Within caliper } \\
(\delta=0.00005) \\
(\mathrm{N}=2817) \\
(6)\end{array}$ & $\begin{array}{l}\text { Radius } \\
(\delta=0.001) \\
(\mathrm{N}=6347) \\
(7)\end{array}$ & $\begin{array}{l}\text { Kernel } \\
(\mathrm{N}=6517) \\
(8)\end{array}$ \\
\hline Ever had sex & $\begin{array}{l}-0.083 * * * \\
(0.025)\end{array}$ & $\begin{array}{l}-0.091 * * * \\
(0.028)\end{array}$ & $\begin{array}{l}-0.067 * * * \\
(0.025)\end{array}$ & $\begin{array}{l}-0.090 * * * \\
(0.027)\end{array}$ & $\begin{array}{l}-0.067 * * \\
(0.031)\end{array}$ & $\begin{array}{l}-0.088 * * * \\
(0.029)\end{array}$ & $\begin{array}{l}-0.075 * * * \\
(0.025)\end{array}$ & $\begin{array}{l}-0.070 * * * \\
(0.023)\end{array}$ \\
\hline $\begin{array}{l}\text { Had sex within } \\
\text { last } 3 \text { months }\end{array}$ & $\begin{array}{l}-0.115 * * * \\
(0.025)\end{array}$ & $\begin{array}{l}-0.071 * * * \\
(0.025)\end{array}$ & $\begin{array}{l}-0.065 * * * \\
(0.025)\end{array}$ & $\begin{array}{l}-0.069 * * * \\
(0.026)\end{array}$ & $\begin{array}{l}-0.045 \\
(0.028)\end{array}$ & $\begin{array}{l}-0.063 * \\
(0.034)\end{array}$ & $\begin{array}{l}-0.067 * * * \\
(0.023)\end{array}$ & $\begin{array}{l}-0.057 * * * \\
(0.022)\end{array}$ \\
\hline Needle use & $\begin{array}{l}-0.045 * * * \\
(0.010)\end{array}$ & $\begin{array}{l}-0.023 * * * \\
(0.010)\end{array}$ & $\begin{array}{l}-0.023 * * \\
(0.009)\end{array}$ & $\begin{array}{l}-0.020 * * \\
(0.008)\end{array}$ & $\begin{array}{l}-0.005 \\
(0.006)\end{array}$ & $\begin{array}{l}0.001 \\
(0.005)\end{array}$ & $\begin{array}{l}-0.022 * * \\
(0.009)\end{array}$ & $\begin{array}{l}-0.026 * * * \\
(0.007)\end{array}$ \\
\hline
\end{tabular}

Notes: (1) Sample is 2009 National Youth Risk Behavior Surveys. (2) Each cell represents a separate average treatment effect on the treated estimate. (3)

Bootstrapped standard errors are reported in parentheses. (4) *, significant at $10 \%$ level; **, significant at $5 \%$ level; ***, significant at $1 \%$ level. 
Table 7: Effect of HIV education on behavioral outcomes (PSM results for full female sample)

\begin{tabular}{|c|c|c|c|c|c|c|c|c|}
\hline Dependent Variable & $\begin{array}{l}\text { OLS results } \\
\text { for comparison } \\
(\mathrm{N}=6983) \\
\text { (1) }\end{array}$ & $\begin{array}{l}\text { Nearest } \\
\text { neighbor } \\
(\mathrm{N}=6926) \\
(2)\end{array}$ & $\begin{array}{l}k \text {-nearest } \\
\text { neighbor } \\
(\mathrm{N}=6926) \\
(3)\end{array}$ & $\begin{array}{l}\text { Within caliper } \\
(\delta=0.001) \\
(\mathrm{N}=6791) \\
(4)\end{array}$ & $\begin{array}{l}\text { Within caliper } \\
(\delta=0.0001) \\
(\mathrm{N}=4314) \\
(5)\end{array}$ & $\begin{array}{l}\text { Within caliper } \\
(\delta=0.00005) \\
(\mathrm{N}=3230) \\
(6)\end{array}$ & $\begin{array}{l}\text { Radius } \\
(\delta=0.001) \\
(\mathrm{N}=6791) \\
(7)\end{array}$ & $\begin{array}{l}\text { Kernel } \\
(\mathrm{N}=6926) \\
(8)\end{array}$ \\
\hline Ever had sex & $\begin{array}{l}-0.009 \\
(0.027)\end{array}$ & $\begin{array}{l}-0.020 \\
(0.027)\end{array}$ & $\begin{array}{l}-0.009 \\
(0.027)\end{array}$ & $\begin{array}{l}-0.019 \\
(0.030)\end{array}$ & $\begin{array}{l}-0.021 \\
(0.029)\end{array}$ & $\begin{array}{l}-0.028 \\
(0.030)\end{array}$ & $\begin{array}{l}-0.010 \\
(0.026)\end{array}$ & $\begin{array}{l}-0.007 \\
(0.023)\end{array}$ \\
\hline $\begin{array}{l}\text { Had sex within } \\
\text { last } 3 \text { months }\end{array}$ & $\begin{array}{l}-0.033 \\
(0.026)\end{array}$ & $\begin{array}{l}-0.041 \\
(0.028)\end{array}$ & $\begin{array}{l}-0.040 * \\
(0.023)\end{array}$ & $\begin{array}{l}-0.039 \\
(0.028)\end{array}$ & $\begin{array}{l}-0.044 * \\
(0.025)\end{array}$ & $\begin{array}{l}-0.047^{*} \\
(0.028)\end{array}$ & $\begin{array}{l}-0.035 \\
(0.023)\end{array}$ & $\begin{array}{l}-0.031 \\
(0.024)\end{array}$ \\
\hline Needle use & $\begin{array}{l}-0.024 * * \\
(0.012)\end{array}$ & $\begin{array}{l}-0.008 \\
(0.006)\end{array}$ & $\begin{array}{l}-0.010 * * \\
(0.005)\end{array}$ & $\begin{array}{l}-0.005 \\
(0.005)\end{array}$ & $\begin{array}{l}-0.000 \\
(0.005)\end{array}$ & $\begin{array}{l}0.003 \\
(0.005)\end{array}$ & $\begin{array}{l}-0.007 \\
(0.005)\end{array}$ & $\begin{array}{l}-0.009 * \\
(0.005)\end{array}$ \\
\hline
\end{tabular}

Notes: (1) Sample is 2009 National Youth Risk Behavior Surveys. (2) Each cell represents a separate average treatment effect on the treated estimate. (3)

Bootstrapped standard errors are reported in parentheses. (4) *, significant at $10 \%$ level; **, significant at $5 \%$ level; ***, significant at $1 \%$ level. 
Table 8: Effect of HIV education on behavioral outcomes (PSM results for sexually experienced male sample)

\begin{tabular}{|c|c|c|c|c|c|c|c|c|}
\hline Dependent Variable & $\begin{array}{l}\text { OLS results } \\
\text { for comparison } \\
(\mathrm{N}=3436) \\
\text { (1) }\end{array}$ & $\begin{array}{l}\text { Nearest } \\
\text { neighbor } \\
(\mathrm{N}=3423) \\
(2)\end{array}$ & $\begin{array}{l}k \text {-nearest } \\
\text { neighbor } \\
(\mathrm{N}=3423) \\
(3)\end{array}$ & $\begin{array}{l}\text { Within caliper } \\
(\delta=0.001) \\
(\mathrm{N}=3199) \\
(4)\end{array}$ & $\begin{array}{l}\text { Within caliper } \\
(\delta=0.0001) \\
(\mathrm{N}=1541) \\
(5)\end{array}$ & $\begin{array}{l}\text { Within caliper } \\
(\delta=0.00005) \\
(\mathrm{N}=1122) \\
(6)\end{array}$ & $\begin{array}{l}\text { Radius } \\
(\delta=0.001) \\
(\mathrm{N}=3199) \\
(7)\end{array}$ & $\begin{array}{l}\text { Kernel } \\
(\mathrm{N}=3432) \\
(8)\end{array}$ \\
\hline $\begin{array}{l}\text { Had sex within } \\
\text { last } 3 \text { months }\end{array}$ & $\begin{array}{l}-0.094 * * * \\
(0.031)\end{array}$ & $\begin{array}{l}-0.006 \\
(0.031)\end{array}$ & $\begin{array}{l}-0.020 \\
(0.030)\end{array}$ & $\begin{array}{l}0.004 \\
(0.030)\end{array}$ & $\begin{array}{l}-0.002 \\
(0.041)\end{array}$ & $\begin{array}{l}0.011 \\
(0.039)\end{array}$ & $\begin{array}{l}-0.009 \\
(0.027)\end{array}$ & $\begin{array}{l}-0.011 \\
(0.031)\end{array}$ \\
\hline $\begin{array}{l}\text { Total sex partners } \\
\text { during lifetime }\end{array}$ & $\begin{array}{l}-0.311 * * \\
(0.143)\end{array}$ & $\begin{array}{l}-0.121 \\
(0.122)\end{array}$ & $\begin{array}{l}-0.229 * \\
(0.129)\end{array}$ & $\begin{array}{l}-0.089 \\
(0.125)\end{array}$ & $\begin{array}{l}-0.054 \\
(0.164)\end{array}$ & $\begin{array}{l}-0.071 \\
(0.177)\end{array}$ & $\begin{array}{l}-0.183 \\
(0.132)\end{array}$ & $\begin{array}{l}-0.139 \\
(0.126)\end{array}$ \\
\hline $\begin{array}{l}\text { Total sex partners } \\
\text { during last } 3 \text { months }\end{array}$ & $\begin{array}{l}-0.477 * * * \\
(0.109)\end{array}$ & $\begin{array}{l}-0.097 \\
(0.094)\end{array}$ & $\begin{array}{l}-0.128 \\
(0.089)\end{array}$ & $\begin{array}{l}-0.055 \\
(0.082)\end{array}$ & $\begin{array}{l}0.003 \\
(0.101)\end{array}$ & $\begin{array}{l}0.011 \\
(0.102)\end{array}$ & $\begin{array}{l}-0.087 \\
(0.080)\end{array}$ & $\begin{array}{l}-0.111 \\
(0.074)\end{array}$ \\
\hline $\begin{array}{l}\text { Last sex with } \\
\text { condom }\end{array}$ & $\begin{array}{l}0.053 \\
(0.035)\end{array}$ & $\begin{array}{l}0.022 \\
(0.031)\end{array}$ & $\begin{array}{l}0.029 \\
(0.029)\end{array}$ & $\begin{array}{l}0.016 \\
(0.031)\end{array}$ & $\begin{array}{l}0.003 \\
(0.039)\end{array}$ & $\begin{array}{l}0.029 \\
(0.045)\end{array}$ & $\begin{array}{l}0.037 \\
(0.034)\end{array}$ & $\begin{array}{l}0.029 \\
(0.028)\end{array}$ \\
\hline $\begin{array}{l}\text { Drug or alcohol use } \\
\text { before last intercourse }\end{array}$ & $\begin{array}{l}-0.071 * * \\
(0.033)\end{array}$ & $\begin{array}{l}-0.003 \\
(0.030)\end{array}$ & $\begin{array}{l}-0.009 \\
(0.026)\end{array}$ & $\begin{array}{l}-0.000 \\
(0.027)\end{array}$ & $\begin{array}{l}-0.008 \\
(0.039)\end{array}$ & $\begin{array}{l}-0.026 \\
(0.047)\end{array}$ & $\begin{array}{l}-0.015 \\
(0.028)\end{array}$ & $\begin{array}{l}-0.023 \\
(0.027)\end{array}$ \\
\hline Needle use & $\begin{array}{l}-0.057 * * \\
(0.016)\end{array}$ & $\begin{array}{l}-0.046 * * * \\
(0.017)\end{array}$ & $\begin{array}{l}-0.027 * * \\
(0.013)\end{array}$ & $\begin{array}{l}-0.044 * * * \\
(0.017)\end{array}$ & $\begin{array}{l}-0.033 * \\
(0.019)\end{array}$ & $\begin{array}{l}-0.046^{*} \\
(0.024)\end{array}$ & $\begin{array}{l}-0.029 * \\
(0.015)\end{array}$ & $\begin{array}{l}-0.026^{* * *} \\
(0.012)\end{array}$ \\
\hline
\end{tabular}

Notes: (1) Sample is 2009 National Youth Risk Behavior Surveys. (2) Each cell represents a separate average treatment effect on the treated estimate. (3) Bootstrapped standard errors are reported in parentheses. (4)*, significant at $10 \%$ level; **, significant at 5\% level; ***, significant at $1 \%$ level. 
Table 9: Effect of HIV education on behavioral outcomes (PSM results for sexually experienced female sample)

\begin{tabular}{|c|c|c|c|c|c|c|c|c|}
\hline Dependent Variable & $\begin{array}{l}\text { OLS results } \\
\text { for comparison } \\
(\mathrm{N}=3323) \\
\text { (1) }\end{array}$ & $\begin{array}{l}\text { Nearest } \\
\text { neighbor } \\
(\mathrm{N}=3272) \\
(2)\end{array}$ & $\begin{array}{l}k \text {-nearest } \\
\text { neighbor } \\
(\mathrm{N}=3272) \\
(3)\end{array}$ & $\begin{array}{l}\text { Within caliper } \\
(\delta=0.001) \\
(\mathrm{N}=3051) \\
(4)\end{array}$ & $\begin{array}{l}\text { Within caliper } \\
(\delta=0.0001) \\
(\mathrm{N}=1264) \\
(5)\end{array}$ & $\begin{array}{l}\text { Within caliper } \\
(\delta=0.00005) \\
(\mathrm{N}=967) \\
(6)\end{array}$ & $\begin{array}{l}\text { Radius } \\
(\delta=0.001) \\
(\mathrm{N}=3051) \\
(7)\end{array}$ & $\begin{array}{l}\text { Kernel } \\
(\mathrm{N}=3272) \\
(8)\end{array}$ \\
\hline $\begin{array}{l}\text { Had sex within } \\
\text { last } 3 \text { months }\end{array}$ & $\begin{array}{l}-0.059 * * \\
(0.030)\end{array}$ & $\begin{array}{l}-0.023 \\
(0.028)\end{array}$ & $\begin{array}{l}-0.045 \\
(0.029)\end{array}$ & $\begin{array}{l}-0.018 \\
(0.029)\end{array}$ & $\begin{array}{l}-0.013 \\
(0.037)\end{array}$ & $\begin{array}{l}0.001 \\
(0.047)\end{array}$ & $\begin{array}{l}-0.037 \\
(0.028)\end{array}$ & $\begin{array}{l}-0.061 * * \\
(0.025)\end{array}$ \\
\hline $\begin{array}{l}\text { Total sex partners } \\
\text { during lifetime }\end{array}$ & $\begin{array}{l}-0.138 \\
(0.140)\end{array}$ & $\begin{array}{l}0.060 \\
(0.135)\end{array}$ & $\begin{array}{l}-0.021 \\
(0.134)\end{array}$ & $\begin{array}{l}0.063 \\
(0.133)\end{array}$ & $\begin{array}{l}0.051 \\
(0.180)\end{array}$ & $\begin{array}{l}0.006 \\
(0.193)\end{array}$ & $\begin{array}{l}0.021 \\
(0.121)\end{array}$ & $\begin{array}{l}-0.046 \\
(0.120)\end{array}$ \\
\hline $\begin{array}{l}\text { Total sex partners } \\
\text { during last } 3 \text { months }\end{array}$ & $\begin{array}{l}-0.274 * * \\
(0.114)\end{array}$ & $\begin{array}{l}-0.075 \\
(0.074)\end{array}$ & $\begin{array}{l}-0.147 * \\
(0.077)\end{array}$ & $\begin{array}{l}-0.067 \\
(0.064)\end{array}$ & $\begin{array}{l}-0.046 \\
(0.075)\end{array}$ & $\begin{array}{l}-0.033 \\
(0.088)\end{array}$ & $\begin{array}{l}-0.105 \\
(0.065)\end{array}$ & $\begin{array}{l}-0.172 * * \\
(0.069)\end{array}$ \\
\hline $\begin{array}{l}\text { Last sex with } \\
\text { condom }\end{array}$ & $\begin{array}{l}0.066 \\
(0.041)\end{array}$ & $\begin{array}{l}0.037 \\
(0.036)\end{array}$ & $\begin{array}{l}0.059 \\
(0.037)\end{array}$ & $\begin{array}{l}0.037 \\
(0.036)\end{array}$ & $\begin{array}{l}0.015 \\
(0.056)\end{array}$ & $\begin{array}{l}0.036 \\
(0.056)\end{array}$ & $\begin{array}{l}0.056 * \\
(0.033)\end{array}$ & $\begin{array}{l}0.081 * * \\
(0.034)\end{array}$ \\
\hline $\begin{array}{l}\text { Drug or alcohol use } \\
\text { before last intercourse }\end{array}$ & $\begin{array}{l}-0.023 \\
(0.031)\end{array}$ & $\begin{array}{l}-0.029 \\
(0.028)\end{array}$ & $\begin{array}{l}-0.001 \\
(0.023)\end{array}$ & $\begin{array}{l}-0.027 \\
(0.026)\end{array}$ & $\begin{array}{l}-0.020 \\
(0.030)\end{array}$ & $\begin{array}{l}-0.012 \\
(0.035)\end{array}$ & $\begin{array}{l}-0.003 \\
(0.025)\end{array}$ & $\begin{array}{l}-0.011 \\
(0.023)\end{array}$ \\
\hline Needle use & $\begin{array}{l}-0.051 * * \\
(0.023)\end{array}$ & $\begin{array}{l}-0.012 \\
(0.011)\end{array}$ & $\begin{array}{l}-0.016 \\
(0.011)\end{array}$ & $\begin{array}{l}-0.012 \\
(0.009)\end{array}$ & $\begin{array}{l}-0.006 \\
(0.010)\end{array}$ & $\begin{array}{l}-0.007 \\
(0.013)\end{array}$ & $\begin{array}{l}-0.012 \\
(0.009)\end{array}$ & $\begin{array}{l}-0.017 \\
(0.011)\end{array}$ \\
\hline
\end{tabular}

Notes: (1) Sample is 2009 National Youth Risk Behavior Surveys. (2) Each cell represents a separate average treatment effect on the treated estimate. (3) Bootstrapped standard errors are reported in parentheses. (4) *, significant at $10 \%$ level; **, significant at 5\% level; ***, significant at $1 \%$ level. 
Table 10: Sensitivity analysis for male needle use

\begin{tabular}{lll}
\hline$e^{\gamma}$ & $\begin{array}{l}\text { P-values } \\
\text { (full male sample) }\end{array}$ & $\begin{array}{l}\text { P-values } \\
\text { (sexually experienced male sample) }\end{array}$ \\
\hline$e^{\gamma}=1$ & $<0.0001$ & $<0.0001$ \\
$e^{\gamma}=1.5$ & $<0.0001$ & $<0.0001$ \\
$e^{\gamma}=2$ & $<0.0001$ & 0.0005 \\
$e^{\gamma}=2.5$ & 0.0002 & 0.0157 \\
$e^{\gamma}=3$ & 0.0048 & 0.1041 \\
$e^{\gamma}=3.5$ & 0.0387 & 0.3053 \\
$e^{\gamma}=4$ & 0.1447 & 0.5271
\end{tabular}

Note: (1) Sample is 2009 National Youth Risk Behavior Survey. (2) These results assess the sensitivity of the PSM estimates from the nearest neighbor matching routine. 


\section{Table A1. Examples of school curriculums}

\begin{tabular}{ll}
\hline State & Examples of lesson topics \\
CA & -Stereotypes and myths regarding
\end{tabular}

(California Dept. of Educ. 2011)

MD

(Maryland Dept. of Educ. 2011)

MI

(Michigan Dept. of Educ. 2011)

$\mathrm{NH}$

(New Hampshire Dept. of Educ. 2011)

NY

(NYC Dept. of Educ. 2010)

WA

(Washington Office of Superintendent of Public Instruction 2011)
-Effects on the human body.

-Transmission myths and facts.

-Recognizing and reducing risks, condom success/failure rates.

-HIV testing, community resources.

-Explain how sexual behaviors including abstinence, condom use, sexual activity, and having multiple sexual partners influence contraction of HIV/AIDS and STIs.

-Explain how other behaviors such as drug use, sharing needles, mother to child, and

occupational exposure influence contraction of HIV/AIDS, STIs, and Hepatitis.

-Clarify the benefits of abstaining from sex or ceasing sex if already sexually active.

-Summarize symptoms, transmission, and consequences.

-Identify ways to avoid risky situations and behaviors.

-Suggest ways to reduce the barriers to condom use.

-Apply steps for correct condom use.

-Conclude that abstinence from sex and drugs are the most effective ways to avoid HIV.

-Effects of alcohol and other drug use on sexual behavior.

-Risks of multiple sexual partners.

-How to make a personal commitment to avoid pregnancy, HIV and other STIs.

-Common routes of transmission of HIV and other STIs.

-Relative risks of specific behaviors.

-Resources for counseling and testing.

-Avoid alcohol and drugs, which may impair judgment and increase risk for HIV/AIDS.

-Encouraged to abstain from sexual intercourse.

-Some lessons address methods of prevention, including the correct use of condoms.

-Address HIV testing.

-Emphasize importance of sexual abstinence outside lawful marriage.

-Teach students about behaviors that place a person at risk for HIV infection. These include the dangers of drug abuse, especially those involving the use of hypodermic

needles; and the dangers of sexual intercourse, with or without condoms.

-Teach that condoms are not a certain means of preventing the spread of HIV and reliance on condoms puts a person at risk for exposure to the disease. 
Table A2: Population-level studies on sex and/or HIV education

\begin{tabular}{|c|c|c|c|c|c|}
\hline Citation & Data & Sample & $\begin{array}{l}\text { Survey measure of } \\
\text { sex and/or HIV education }\end{array}$ & Methods & $\begin{array}{l}\text { Treatment of } \\
\text { endogenous } \\
\text { education }\end{array}$ \\
\hline $\begin{array}{l}\text { Anderson et al. (1990) } \\
\text { Family Planning }\end{array}$ & $\begin{array}{l}1989 \text { Secondary School } \\
\text { Student Health Risk Survey }\end{array}$ & $\begin{array}{l}\text { Males and females } \\
\text { grades } 9-12\end{array}$ & $\begin{array}{l}\text { Respondent self-report } \\
\text { of having received education }\end{array}$ & $\begin{array}{l}\text { Logistic } \\
\text { regression }\end{array}$ & No \\
\hline
\end{tabular}

Perspectives

Summary of findings:

-No association between AIDS instruction in school and sexual behaviors when controlling for knowledge about HIV and AIDS.

-Additional knowledge about HIV and AIDS is associated with having fewer sexual partners and using condoms more frequently.

$\begin{array}{llll}\text { Billy et al. (1994) } & \begin{array}{l}\text { 1982 National Survey } \\ \text { of Family Growth }\end{array} & \text { Females aged 15-19 } & \begin{array}{l}\text { Respondent self-report } \\ \text { of having received education }\end{array}\end{array}$

and the Family

Summary of findings:

-Birth control instruction was associated with a decreased likelihood of premarital intercourse among nonblack females.

$\begin{array}{llll}\text { Dawson (1986) } & \text { 1982 National Survey } & \text { Females aged 15-19 } & \begin{array}{l}\text { Respondent self-report } \\ \text { of hamily Planning }\end{array}\end{array}$

Summary of findings:

-No association between exposure to sex education and sexual debut.

-Exposure to sex education is associated with an increase in contraceptive knowledge and use among sexually active females.

$\begin{array}{llll}\text { Furstenberg et al. (1985) } & \text { 1981 National Survey } & \text { Males and females } & \text { Respondent self-report } \\ \text { American Journal of } & \text { of Children } & & \begin{array}{l}\text { Comparison of } \\ \text { Public Health }\end{array}\end{array}$

Summary of findings:

-Exposure to sex education was associated with a lower rate of sexual intercourse initiation. 
Table A2: Population-level studies on sex and/or HIV education (continued)

\begin{tabular}{|c|c|c|c|c|c|}
\hline Citation & Data & Sample & $\begin{array}{l}\text { Survey measure of } \\
\text { sex and/or HIV education }\end{array}$ & Methods & $\begin{array}{l}\text { Treatment of } \\
\text { endogenous } \\
\text { education }\end{array}$ \\
\hline $\begin{array}{l}\text { Holtzman et al. (1994) } \\
\text { American Journal of }\end{array}$ & $\begin{array}{l}\text { 1989 Secondary School } \\
\text { Student Health Risk Survey; }\end{array}$ & $\begin{array}{l}\text { Males and females } \\
\text { grades } 9-12\end{array}$ & $\begin{array}{l}\text { Respondent self-report } \\
\text { of having received education }\end{array}$ & $\begin{array}{l}\text { Logistic } \\
\text { regression }\end{array}$ & No \\
\hline
\end{tabular}

Public Health

1990 Youth Risk Behavior

of having received education regression

Survey

Summary of findings:

-For both surveys, HIV knowledge was associated with fewer sex partners and a lower rate of needle use.

$\begin{array}{llll}\text { Isley et al. (2010) } & 2002 \text { National Survey } & \text { Females aged 15-19 } & \text { Respondent self-report } \\ \text { of Family Growth } & & \text { Logistic having received education } & \text { Nogression }\end{array}$

Summary of findings:

-No association between type of sex education and contraceptive use at first intercourse.

-Abstinence-only messaging was associated with decreased reliable contraceptive method use at first intercourse.

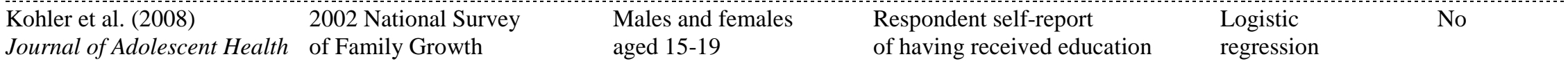

Summary of findings:

-Adolescents who received comprehensive sex education were less likely to report teenage pregnancy.

-No association between abstinence-only sex education and pregnancy.

-No association between abstinence-only sex education and vaginal intercourse.

-Comprehensive sex education was marginally associated with a lower likelihood of vaginal intercourse.

-No associate between comprehensive or abstinence-only sex education and STI contraction.

$\begin{array}{llll}\text { Ku et al. (1992) } & \text { 1988 National Survey } & \text { Males aged 15-19 } & \text { Respondent self-report } \\ \text { Family Planning } & \text { of Adolescent Males } & & \text { Tobit } \\ \text { Perspectives } & & \text { regression received education }\end{array}$

Summary of findings:

-AIDS and sex education was associated with modest but significant decreases in the number of sexual partners and frequency of intercourse.

-AIDS and sex education was associated with more consistent condom use. 
Table A2: Population-level studies on sex and/or HIV education (continued)

\begin{tabular}{|c|c|c|c|c|c|}
\hline Citation & Data & Sample & $\begin{array}{l}\text { Survey measure of } \\
\text { sex and/or HIV education }\end{array}$ & Methods & $\begin{array}{l}\text { Treatment of } \\
\text { endogenous } \\
\text { education }\end{array}$ \\
\hline $\begin{array}{l}\text { Ku et al. (1993) } \\
\text { Public Health Reports }\end{array}$ & $\begin{array}{l}1988 \text { National Survey } \\
\text { of Adolescent Males }\end{array}$ & Males aged 15-19 & $\begin{array}{l}\text { Respondent self-report } \\
\text { of having received education }\end{array}$ & $\begin{array}{l}\text { Logistic } \\
\text { regression and } \\
\text { discrete time- } \\
\text { event models }\end{array}$ & No \\
\hline
\end{tabular}

Summary of findings:

-Instruction about AIDS and resistance skills was associated with delays in first intercourse.

-Instruction about biological aspects of sexuality and birth control was associated with earlier first intercourse.

$\begin{array}{llll}\begin{array}{l}\text { Manlove et al. (2008) } \\ \text { Journal of Adolescent Health }\end{array} & \begin{array}{l}2002 \text { National Survey } \\ \text { of Family Growth }\end{array} & \text { Males aged 15-19 } & \begin{array}{l}\text { Respondent self-report } \\ \text { of having received education }\end{array}\end{array}$

Summary of findings:

-Hispanic males who received sex education were more likely to use condoms.

$\begin{array}{llll}\begin{array}{l}\text { Marsiglio and Mott (1986) } \\ \text { Family Planning } \\ \text { Perspectives }\end{array} & \begin{array}{l}\text { 1984 National Longitudinal } \\ \text { Survey of Work Experience } \\ \text { of Youth }\end{array} & \begin{array}{l}\text { Males and Females } \\ \text { aged 19-27 }\end{array} & \begin{array}{l}\text { Respondent self-report } \\ \text { of having received education }\end{array} \\ \text { regression }\end{array}$

Summary of findings:

-Females who received sex education were slightly more likely to initiate sexual activity at ages 15 and 16 .

-Older sexually active females who received sex education were significantly more likely to use effective contraceptive methods.

$\begin{array}{llll}\text { Mauldon and Luker (1996) } & 1988 \text { National Survey } & \text { Females aged 15-24 } & \begin{array}{l}\text { Respondent self-report } \\ \text { of having received education }\end{array}\end{array}$

Summary of findings:

-Exposure to formal contraceptive education was associated with an increased likelihood of contraception use at first intercourse. 


\section{Table A2: Population-level studies on sex and/or HIV education (continued)}

\begin{tabular}{llll}
\hline Citation & Data & Sample & $\begin{array}{l}\text { Treatment of } \\
\text { endogenous } \\
\text { sex and/or HIV education }\end{array}$ \\
$\begin{array}{l}\text { Mueller et al. (2008) } \\
\text { Journal of Adolescent Health }\end{array}$ & $\begin{array}{l}\text { 2002 National Survey } \\
\text { of Family Growth }\end{array}$ & $\begin{array}{l}\text { Males and females } \\
\text { aged 15-19 }\end{array}$ & $\begin{array}{l}\text { Respondent self-report } \\
\text { of having received education }\end{array}$
\end{tabular}

Summary of findings:

-Males who received sex education were less likely to have had sex and more likely to have used birth control during first intercourse.

-Adolescents who received sex education were more likely to postpone sexual intercourse until age 15.

-No association between sex education and birth control use for females.

\begin{tabular}{|c|c|c|c|c|}
\hline $\begin{array}{l}\text { Oettinger (1999) } \\
\text { Journal of Political Economy }\end{array}$ & $\begin{array}{l}1979 \text { National Longitudinal } \\
\text { Survey of Youth }\end{array}$ & $\begin{array}{l}\text { Males and females } \\
\text { aged } 10-19\end{array}$ & $\begin{array}{l}\text { Respondent self-report } \\
\text { of having received education }\end{array}$ & $\begin{array}{l}\text { Hazard rate models } \\
\text { with same-sex sibling } \\
\text { fixed effects }\end{array}$ \\
\hline
\end{tabular}

-Sex education was associated with earlier sexual activity for females.

-Sex education was associated with earlier pregnancy for some groups of females.

-No association between sex education and male transitions into sexual activity.

\begin{tabular}{|c|c|c|c|c|}
\hline $\begin{array}{l}\text { Sabia (2006) } \\
\text { Journal of Policy Analysis } \\
\text { and Management }\end{array}$ & $\begin{array}{l}\text { 1994-1995 National } \\
\text { Longitudinal Study of } \\
\text { Adolescent Health }\end{array}$ & $\begin{array}{l}\text { Males and females } \\
\text { grades } 7-9\end{array}$ & $\begin{array}{l}\text { School administrator report } \\
\text { of whether education is offered }\end{array}$ & $\begin{array}{l}\text { OLS, propensity } \\
\text { score matching, } \\
\text { fixed effects, and } \\
\text { instrumental vari. }\end{array}$ \\
\hline
\end{tabular}

Summary of findings:

-Little evidence exists of a causal link between sex education and sexual behavior after controlling for unobserved heterogeneity.

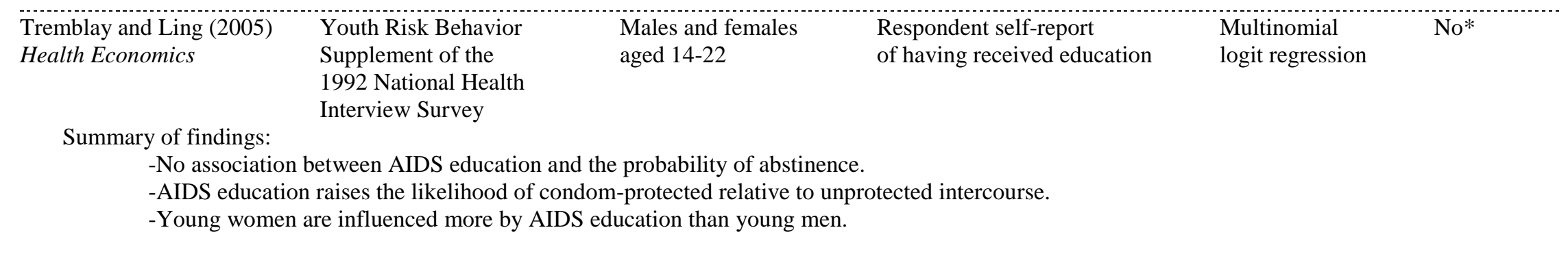

*Using a Hausman-type test, Tremblay and Ling (2005) fail to reject the null hypothesis of exogeneity and only report results where HIV education is assumed to be exogenous. 
Table A3: The distribution of students by HIV education status within each block

\begin{tabular}{|c|c|c|c|}
\hline \multicolumn{4}{|c|}{$\underline{\text { Full male sample }}$} \\
\hline Block & HIV ed. = 1 & HIV ed. $=0$ & Total \\
\hline 1 & 1 & 0 & 1 \\
\hline 2 & 38 & 26 & 64 \\
\hline 3 & 80 & 36 & 116 \\
\hline 4 & 340 & 69 & 409 \\
\hline 5 & 1815 & 224 & 2039 \\
\hline 6 & 2940 & 203 & 3143 \\
\hline 7 & 722 & 34 & 756 \\
\hline Total & 5936 & 592 & 6528 \\
\hline \multicolumn{4}{|c|}{ Full female sample } \\
\hline Block & HIV ed. = 1 & HIV ed. $=0$ & Total \\
\hline 1 & 28 & 12 & 40 \\
\hline 2 & 286 & 70 & 356 \\
\hline 3 & 1765 & 212 & 1977 \\
\hline 4 & 3284 & 228 & 3512 \\
\hline 5 & 1046 & 51 & 1097 \\
\hline Total & 6409 & 573 & 6982 \\
\hline \multicolumn{4}{|c|}{$\underline{\text { Sexually experienced male sample }}$} \\
\hline Block & HIV ed. = 1 & HIV ed. $=0$ & Total \\
\hline 1 & 2 & 1 & 3 \\
\hline 2 & 44 & 36 & 80 \\
\hline 3 & 319 & 76 & 395 \\
\hline 4 & 1079 & 131 & 1210 \\
\hline 5 & 1627 & 121 & 1748 \\
\hline Total & 3071 & 365 & 3436 \\
\hline \multicolumn{4}{|c|}{ Sexually experienced female sample } \\
\hline Block & HIV ed. = 1 & HIV ed. $=0$ & Total \\
\hline 1 & 9 & 5 & 14 \\
\hline 2 & 159 & 36 & 195 \\
\hline 3 & 992 & 127 & 1119 \\
\hline 4 & 1887 & 107 & 1994 \\
\hline Total & 3047 & 275 & 3322 \\
\hline
\end{tabular}

Note: (1) Sample is 2009 National Youth Risk Behavior Survey. 